\title{
Oleksandr KASHCHUK*
}

\section{LOGOS-SARX CHRISTOLOGY AND THE SIXTH-CENTURY MIAENERGISM}

From the early years of Christian theology to the Council of Ephesus (431) the main task for Christology was to affirm the reality of both divinity and humanity in the person of Christ. Each of the great theological centers, such as Antioch and Alexandria, was to emphasize a different aspect of Christology in defense of orthodoxy. After the Council of Nicaea (325) the adherents of consubstantial (ópoovoros) saw difficulty in defining the reality of Christ's humanity. This question arose in the period between Nicaea and Ephesus (325431). Bishops and theologians stressed the unity of subject of Christ and the truth of his humanity. Although during the time from Ephesus to Chalcedon (431-451) the fullness of divinity and humanity were acknowledged by majority, there arose the debate concerning the relationship between the human and divine elements within Christ on the one hand and relationship between these elements on the other. The debate passed into the question concerning the expression of Christ's two natures coexisting in one person. So the main focus of the Christological discussion in the sixth century shifted from the problem of unity and interrelation between elements in Christ to the expression of unity through activity and its consequences for the fullness of Christ's humanity. The issue of Christ's operation and will thus became the most prevalent questions in Christology from the late sixth to the early seventh centuries. At that time there arose the Miaenergist debate concerning whether Christ had a wholly human as well as a wholly divine operation and volition.

In the context of the Miaenergism, which is the idea of Christ having one divine-human operation, it should be emphasized that already in the ancient anthropology there existed conviction that volition and operation was bound to reasonable part of the human soul. Although in ancient philosophy neither Plato (428/427 BC - 348/347 BC) nor Aristotle (384-322 BC) had a clear notion of a will, they knew a closely related idea of somebody's willing or wanting something, namely the notion of volition or intention (ßov́ $\lambda \varepsilon \sigma \theta \alpha i$ or

\footnotetext{
* Oleksandr Kashchuk Ph.D. - Assistant Professor in the Department of History of the Middle Ages and Byzantium at the Faculty of History of Lviv Ivan Franko National University and Assistant Professor in the Department of Theology at the Faculty of Philosophy and Theology of Lviv Ukrainian Catholic University; e-mail: oleks_andr@ucu.edu.ua.
} 
$\beta o v ́ \lambda \eta \sigma ı)^{1}$. Plato seems to demonstrate that volition belongs to the reasonable part of the soul but it is dependent on the affections of the other parts of the human soul ${ }^{2}$. Also Aristotle conceived of volition as a power of soul ${ }^{3}$. He stated also that volition may be influenced by emotions ${ }^{4}$. For both Plato and Aristotle volition thus is a form of desire which is bound to soul ${ }^{5}$. Generally Platonists, Epicureans, and stoics alike referred the whole problem of human activity to the state of the human mind 6 .

The idea of relation between reason and volition was also present in the Holy Scripture. There was not a fixed term for volition or a free will, but the concept as such was present ${ }^{7}$. For example in Paul intention as such is identi-

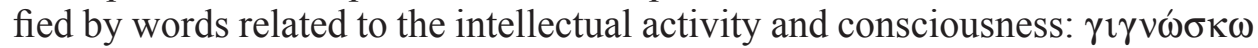

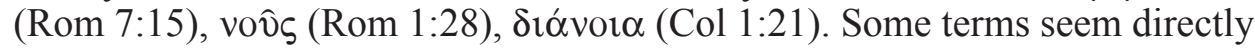
to denote volition in connection with the intellectual activity: $\theta \dot{\varepsilon} \lambda \eta \mu \alpha$ (1Cor 16:12 and 7:37), ßov́ $\lambda$ o $\mu \alpha \mathrm{l}$ (2Cor 1:17) ${ }^{8}$. There are also passages which hint at the human soul of Christ (Mt 26:38), his human intention (Jn 1:43; 7:11; Mk $9: 30 ; 7: 24)$ and will (Mt 26:39). These passages will be the subject of discussion among theologians, especially during the Miaenergist and the Miathelite debate of the sixth and seventh centuries.

The purpose of the article is to argue that the Logos-sarx Christology was a ground for the rise of the sixth-century Miaenergism. The paper will be divided into six parts. The first part as a short introduction will briefly present the origins of formulation of belief in the divinity and humanity of Christ and its consequences for the fundamental ideas of Christ's operation. The second part will centre generally on the Alexandrian type of Christology as a pillar of the Logos-sarx model. The aim of the third part is to show the outlines of the Christology of Ephesus and Chalcedon as alternative to that of Alexandria. The fourth and the fifth part of the paper will focus on the pro-Alexandrian and neo-Chalcedonian kind of reasoning in the period after Chalcedon.

${ }^{1}$ Cf. A. Dihle, The Theory of Will in Classical Antiquity, Berkeley - Los Angeles - London 1982, 19-20.

${ }^{2}$ Cf. Plato, Timaeus 81e - 87a and 70 a-b. See Dihle, The Theory of Will, p. 39-40 and 53-54.

${ }^{3}$ Cf. Aristoteles, De anima II 3, 414a29 - 414b5, ed. G. Biehl, Lipsiae 1896, 36. Cf. J. Greig, The Dilemma of Deliberation: On the faculty and Mode of Willing in Aristotle and Maximus the Confessor, https://www.scribd.com/document/127364720/On-the-Faculty-and-Mode-of-Willingin-Aristotle-and-Maximus-the-Confessor, 2-6 [08.04.2017].

${ }^{4}$ Cf. Aristoteles, Ethica nicomachea 1111 b - 1115a, ed. F. Susemihl - O. Apelt, Lipsiae 1903, 47-56. See Dihle, The Theory of Will, p. 47-56.

${ }^{5}$ Cf. M. Frede, A Free Will. Origins of the Notion in Ancient Thought, Berkeley - Los Angeles - London 2011, 20-21.

${ }^{6}$ Cf. Dihle, The Theory of Will, p. 41-42. The concept of volition as a faculty of the rational soul was also known in Latin anthropology. See N.W. Gilbert, The Concept of Will in Early Latin Philosophy, "Journal of the History of Philosophy" 1 (1963) fasc. 1, 17-35.

${ }^{7}$ Cf. Dihle, The Theory of Will, p. 79.

${ }^{8}$ Cf. ibidem, p. 86, footnote 80 . 
The sixth part gives attention to the origins of the Miaenergist debate of the sixth and seventh century.

1. The origins of formulating the truth about the divine-human being of Christ. Already in the early years of Christian theology Ignatius of Antioch (c. 35 - c. 108) emphasized both the oneness of Christ and the reality of His twofold mode of being ${ }^{9}$ in opposition to religious groups or thinkers which denied any of the two realities. For example, the group of Ebionists denied Christ's divinity ${ }^{10}$ and Docetists taught that Christ's humanity was unreal ${ }^{11}$.

The need of affirmation of Christ's divinity was actualized in polemics with Judaism and paganism. In the second century Justin Martyr (c. 100-165) argues the humanity and divinity of Christ, but focuses especially on the divinity $^{12}$. He teaches that the incarnate Logos is the same as the pre-existent Logos $^{13}$. In Christ the Logos was united with man. The Logos thus has appeared in history as body and reason and soul ${ }^{14}$. John Norman Davidson Kelly (19091997) supposes that in Justin's teaching the reason might have meant the Logos. It would have meant that the Logos took the place of the human reasonable soul in the humanity of Christ and was his principle of operation. If this supposition is correct, then Justin might have been a pioneer of the Logos-sarx type of Christology. He might have regarded Logos as the governing principle in Christ's humanity. Since Justin showed little interest in Christ's human soul and its properties, it is not easy to formulate final conclusions on this topic ${ }^{15}$.

Irenaeus of Lyon († c. 202) defended the reality of both divinity and humanity in Christ in opposition to Gnostics ${ }^{16}$. Christ is the same as the preexistent Logos. Through him were created all beings. Accordingly, the Logos

${ }^{9}$ Cf. Ignatius Antiochenus, Epistula ad Trallenses 9, 1-1, ed. Th. Camelot, SCh 10, Paris 1951, 118; idem, Epistula ad Ephesios 18, 2, SCh 10, 86; idem, Epistula ad Smyrnenses 1, 1-2, SCh 10, 154-156. Cf. J.N.D Kelly, Early Christian Doctrines, London 1968, 142-144; B. Sesboüé, Treść tradycji: reguta wiary i symbole (II-V wiek), in: Historia dogmatów, vol. 1: Bóg zbawienia, ed. B. Sesboüé - J. Wolinski, transl. into Polish P. Rak, Kraków 1999, 76-77.

${ }^{10}$ Cf. Kelly, Early Christian Doctrines, p. 139; J. Daniélou - H.I. Marrou, The Christian Centuries, vol. 1: The First Six Hundred Years, transl. into English V. Cronin, London 1964, 56-57.

${ }^{11}$ Cf. Kelly, Early Christian Doctrines, p. 141.

${ }^{12}$ Cf. Iustinus, Apologia I 30-54, ed. M. Marcovich, in: Iustinus, Apologiae pro Christianis, Dialogus cum Tryphone, PTS 38, Berlin - New York 1994, 76-109. See A. Grillmeier, Christ in Christian Tradition, vol. 1: From the Apostolic Age to Chalcedon (451), transl. into English J. Bowden, Atlanta 1975, 89.

${ }^{13}$ Cf. Grillmeier, Christ in Christian Tradition, I, p. 90; Kelly, Early Christian Doctrines, p. 145.

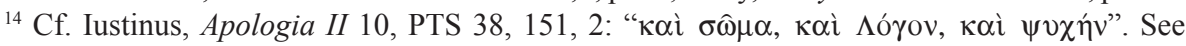
Grillmeier, Christ in Christian Tradition, I, p. 93-94.

${ }^{15}$ Cf. Kelly, Early Christian Doctrines, p. 146-147.

${ }^{16}$ Cf. Irenaeus, Adversus haereses IV 6, 7, ed A. Rousseau, SCh 100, Paris 1955, 452: "quoniam vere homo et quoniam vere Deus". See Kelly, Early Christian Doctrines, p. 147; Grillmeier, Christ in Christian Tradition, I, p. 99. 
on account of the Incarnation is also the head of the visible world ${ }^{17}$. Christ's incarnation is a unity of the Logos and real body. He has become what human beings are, namely body and soul which assumes Spirit from God ${ }^{18}$. Irenaeus does not deny the soul of Christ, since the perfect human being consists of the flesh, soul and spirit ${ }^{19}$. Nevertheless it seems that Irenaeus does not focuses on the theological significance of Christ's soul and his operation.

Turtullian (c. 155 - c. 220/240) was the author who greatly influenced the West. He is convinced that each element of Christ's person, divinity and humanity, preserves its properties and the sphere of activity ${ }^{20}$. Tertullian teaches also of communicatio idiomatum ${ }^{21}$. This means that he emphasized that Christ's humanity was real and was formed of soul and body ${ }^{22}$. Christ has assumed a genuine human soul in order to save whole $\operatorname{man}^{23}$. The soul experienced human mental experiences ${ }^{24}$. Christ really suffered ${ }^{25}$ and experienced hunger, tears, birth and death ${ }^{26}$. Nevertheless there are passages which hint that the governing principle of humanity is the Logos ${ }^{27}$. Yet J.N.D. Kelly states that Tertullian acknowledges possibility of human element as an active factor ${ }^{28}$. Accordingly, Tertullian seems to acknowledge a genuine human operation in Christ.

${ }^{17}$ Cf. Irenaeus, Adversus haereses III 16, 6, ed. A. Rousseau - L. Doutreleau, SCh 211, Paris 1974, 310-314. See Kelly, Early Christian Doctrines, p. 147; Grillmeier, Christ in Christian Tradition, I, p. 102.

${ }^{18}$ Cf. Irenaeus, Adversus haereses III 22, 1, SCh 211, 432: "quod nos eramus [...] Nos autem quoniam corpus sumus de terra acceptum et anima accipiens a Deo Spiritum". See Grillmeier, Christ in Christian Tradition, I, p. 103.

${ }^{19}$ Cf. Irenaeus, Adversus haereses V 9, 1, ed. A. Rousseau, SCh 153, Paris 1969, 106: "perfectus homo constat, carne, anima et spiritu". See Grillmeier, Christ in Christian Tradition, I, p. 103; Kelly, Early Christian Doctrines, p. 148-149.

${ }^{20}$ Cf. Tertullianus, Adversus Praxean 27, ed. A. Kroymann, CSEL 47, Lipsiae 1906 281-282: "uidemus duplicem statum, non confusum. Sed coniunctum, in una persona, deum et hominem Iesum, - de Christo enim differo - et adeo salua est utriusque proprietas substantiae, ut et spiritus res suas egerit in illo, id est uirtutes et opera et signa, et caro passiones suas functa sit”. See Kelly, Early Christian Doctrines, p. 150-151.

${ }^{21}$ Cf. Tertullianus, De carne Christi 5, ed. J.-P. Mahé, SCh 216, Paris 1975, 226-232.

${ }^{22}$ Cf. ibidem, SCh 216, 230: "Ita utriusque substantiae census hominem et Deum exhibuit"; ibidem 1, SCh 216, 210-212; ibidem 5, SCh 216, 226-232; ibidem 9, SCh 216, 250-254.

${ }^{23}$ Cf. ibidem 10, SCh 216, 256: "Deinde, si animas nostras per illam, quam gestavit, liberare susceperat, illam quoque, quam gestavit, nostrum gestasse debuerat, id est nostrae formae, cuiuscumque formae est in occulto anima nostra, non tamen carneae"; ibidem 13, SCh 216, 264-268.

${ }^{24}$ Cf. ibdem 5, SCh 216, 226-232; idem, Adversus Praxean 27, CSEL 47, 282. See Kelly, Early Christian Doctrines, p. 152.

${ }^{25}$ Cf. Tertullianus, Adversus Praxean 29, CSEL 47, 285-286.

${ }^{26} \mathrm{Cf}$. ibidem 16, CSEL 47, 258.

${ }^{27}$ Cf. idem, Adversus Marcionem II 27, ed. A. Kroymann, CSEL 47, 373: "nam et profitemur Christum semper egisse in dei patris nomine, ipsum ab initio conuersatum, ipsum congressum cum patriarchis et prophetis, filium creatoris, sermonem eius, quem ex semetipso proferendo filium fecit et exinde omni dispositioni suae uoluntatique praefecit".

${ }^{28}$ Cf. Kelly, Early Christian Doctrines, p. 152. 
There was also a type of Christology which articulated the humanity of Christ in opposition to those who asserted its unreal character. Paul of Samosata (200-275) stated that Christ was born as a mere $\operatorname{man}^{29}$ with a human $\operatorname{soul}^{30}$. The Logos descended upon Him as upon a mere man ${ }^{31}$. It sounded as blasphemous to Alexandrian theologians, but quite a number of Syrian Christians supported it ${ }^{32}$. Paul's Christology influenced that of Eustathius of Antioch $\left(\dagger\right.$ c. 337/346), who recognized the human soul of Christ ${ }^{33}$. This type of Christology seems to foreshadow that of the Antiochean School $^{34}$, namely the Logos-anthropos model.

The significant centre of Christological reflection in the Greek-speaking world of the third century was Alexandria. Clemens of Alexandria (c. 150 - c. 215) teaches that the Logos begotten of the Father is the same who has become flesh ${ }^{35}$. Clemens maintains the reality of the humanity of Christ ${ }^{36}$. Christ thus is both God and $\operatorname{man}^{37}$.

In anthropology Clemens of Alexandria developed idea of interrelation between the reason and moral conduct of human being. It is important for the understanding of the future Miaenergist debate. Clemens is convinced that the

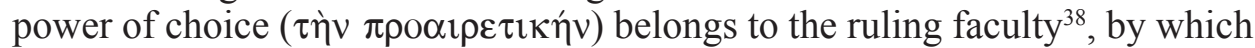
human beings reason $(\delta 1 \alpha \lambda \mathrm{o} \gamma i \zeta o ́ \mu \varepsilon \theta \alpha)^{39}$. Reason is the governing principle of human being. Then the lower soul must be an instrument in the service of the reason ${ }^{40}$. Clemens makes distinction between the mind and the corporeal spirit

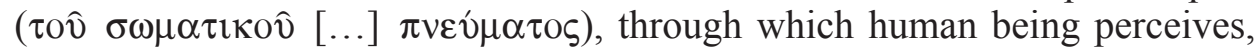

\footnotetext{
${ }^{29}$ Cf. Eusebius Caesariensis, HE VII 27, 2, ed. G. Bardy, SCh 41, Paris 1955, 211-212; ibidem VII 30, 11, SCh 41, 217. See Kelly, Early Christian Doctrines, p. 140.

${ }^{30}$ Cf. Eusebius Caesariensis, De ecclesiastica theologia I 20,43-44, ed. E. Klostermann, GCS 14, Eusebius Werke 4, Leipzig 1906, 88.

${ }^{31}$ Cf. Kelly, Early Christian Doctrines, p. 140.

${ }^{32}$ Cf. W.H.C. Frend, The Rise of the Monophysite Movement: Chapters in the History of the Church in the Fifth and Sixth Centuries, Cambridge 2008, 108.

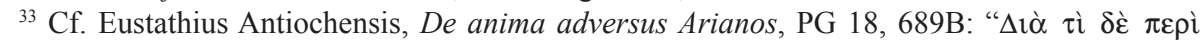

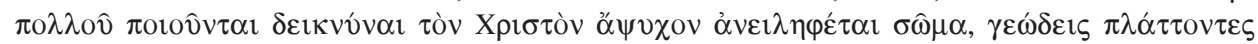

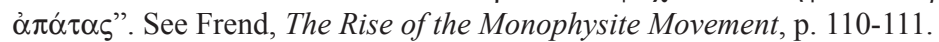

${ }^{34} \mathrm{Cf}$. Frend, The Rise of the Monophysite Movement, p. 110-112.

${ }^{35}$ Cf. Clemens Alexandrinus, Excerpta e Theodoto 7, 4, ed. F.-M. Sagnard, SCh 23, Paris 1970 , 70; ibidem 8, 1-2, SCh 23, 72; idem, Protrepticus 6, 4 - 7, 2, ed. C. Mondesert, SCh 2, Paris 1949, 60. See Grillmeier, Christ in Christian Tradition, I, p. 135.

${ }^{36}$ Cf. Clemens Alexandrinus, Stromata V 16, 1-7, ed. O. Stählin, GCS 15, Leipzig 1906, 336. See Grillmeier, Christ in Christian Tradition, I, p. 136.

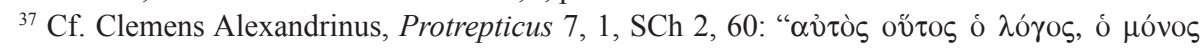

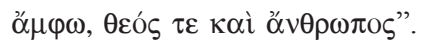

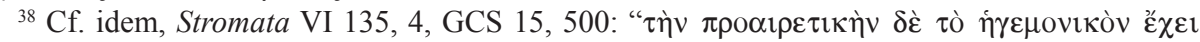

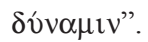

${ }^{39}$ Cf. ibidem VI 136, 1, GCS 15, 500.

${ }^{40}$ Cf. idem, Paedagogus III 1, 1 - 3, 3, ed. C. Mondesert - Ch. Matray - H.I. Marrou, SCh 158, Paris 1970, 12-16. See Grillmeier, Christ in Christian Tradition, I, p. 137.
} 
desires, rejoices and growth ${ }^{41}$. To the corporeal or carnal spirit ( $\tau$ ò $\pi v \varepsilon \hat{v} \mu \alpha$

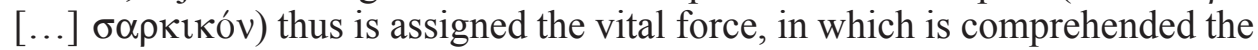
power of nutrition and growth, and generally of motion ${ }^{42}$.

The carnal spirit is involved in producing actions. It is by it that thoughts and conceptions advance to actions ( $\tau \grave{\alpha} \varsigma \pi \rho \alpha ́ \xi \varepsilon 1 \varsigma)$. When the corporeal spirit masters the desires, the ruling faculty reigns, since the man performs good actions by the faculty of reason ${ }^{43}$. Actions are twofold - those of thought and those of act ${ }^{44}$, since the movements of the senses are both impressed in the mind and manifested in the activity which proceeds from the body ${ }^{45}$.

For Clemens of Alexandria the humanity of Christ from the soteriological point of view seems to have no active role ${ }^{46}$. Accordingly, the human operation of Christ seems to be reduced only to the carnal spirit; the Logos might have taken the role of reason.

Origen (184/185 - 253/254) teaches of Christ's humanity and divinity ${ }^{47}$. The Logos is one with the human nature ${ }^{48}$. Origen emphasizes that Christ's human soul filled with reason (substantia rationabilis) $)^{49}$ pre-existed from eternity and has become one spirit with $\operatorname{God}^{50}$. It is the link between the Logos and the body $^{51}$. On account of this it is filled with the divine wisdom, goodness, truth and life. Christ's soul was similar to ours according to nature, but according to power it was similar to Himself and incapable of $\sin ^{52}$. It seems that the soul of

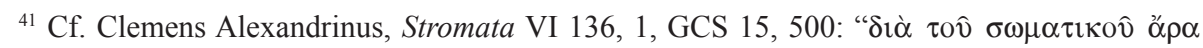

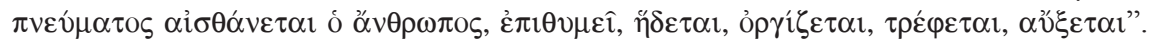

${ }^{42}$ Cf. ibidem VI 135, 3, GCS 15, 500.

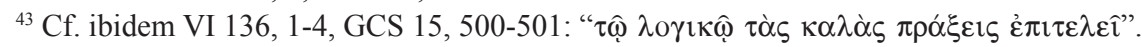

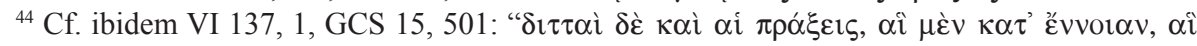

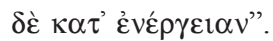

${ }^{45}$ Cf. ibidem VI 136, 5, GCS 15, 501.

${ }^{46}$ Cf. Kelly, Early Christian Doctrines, p. 154; Grillmeier, Christ in Christian Tradition, I, p. $137-138$.

${ }^{47}$ Cf. H. Crouzel, Orygenes, transl. into Polish J. Margański, Kraków 2004, 232-245; Kelly, Early Christian Doctrines, p. 155-156.

${ }^{48}$ Cf. Origenes, Contra Celsum 2, 9, ed. M. Borret, SCh 132, Paris 1967, 302-306, especially

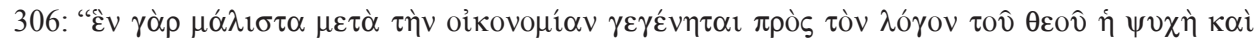

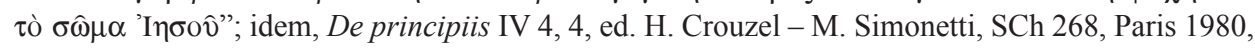
408; idem, Contra Celsum 6, 47-48, ed. M. Borret, SCh 147, Paris 1969, 296-300.

${ }^{49}$ Cf. Origenes, Contra Celsum 2, 9, SCh 132, 302-304; idem, De principiis IV 4, 4, SCh 268, 408-410. See Kelly, Early Christian Doctrines, p. 156.

${ }^{50}$ Cf. Origenes, De principiis II 6, 3, ed. H. Crouzel - M. Simonetti, SCh 252, Paris 1978, 314 : "illa anima $[\ldots]$ facta est cum ipso principaliter unus spiritus".

${ }^{51} \mathrm{Cf}$. ibidem: "Hac ergo substantia animae inter deum carnemque mediante (non enim possible erat dei naturam corpori sine mediatore misceri) nascitur". See Grillmeier, Christ in Christian Tradition, I, p. 146; Frend, The Rise of the Monophysite Movement, p. 107.

${ }^{52} \mathrm{Cf}$. Origenes, De principiis IV 4, 4, SCh 268, 408: "suscepit non solum corpus humanum, [...] sed et animam, nostrarum quidem animarum similem per naturam, proposito uero et uirtute simile 
Christ was conceived as a subject of activity ${ }^{53}$, but this soul was subordinate to the Logos, so it was passive ${ }^{54}$. Accordingly, the human operation of Christ was not specially envisaged.

There were thus expressed the origins of the two alternative types of Christology during the first centuries of Christian theology - the Logos-anthropos and the Logos-sarx. The first was represented by Ignatius of Antioch, Tertullian, Paul of Samosata and Eustathius of Antioch. The adherents of the latter were Justin, Clemens of Alexandria and Origen. The first model of Christology acknowledges a genuine human soul of Christ and, consequently, the possibility of human element as an active factor. In the latter model of Christology the volition and operation of Christ must flow from the Logos. Human mind, though not denied, was conceived as a passive element. Accordingly, Logossarx Christology tends to devaluate a human mind as a governing principle in Christ $^{55}$. But the issue of Christ's volition did not belong to the most important questions of Christology at that time; it would emerge later.

2. The Alexandrian Christology as a pillar of the Logos-sarx model. The Council of Nicaea (325) had officially affirmed that Christ is fully God $^{56}$. Nicaean creed contained also statement that the Son became a human being ${ }^{57}$. It was aimed against the Arians who taught that in Christ the Logos had united himself to a human body lacking a reasonable soul, himself taking the place of one ${ }^{58}$. After the Council quite a number of the adherents of the term con-

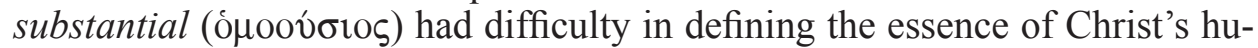
manity and its manner of unity to divinity. The question arose in the period between Nicaea and Ephesus (325-431).

At that time one of the most remarkable centers of Christology was Alexandria. Athanasius of Alexandria (c. 296-373) denied that Christ's flesh was deprived of the soul or of the mind ${ }^{59}$. Nevertheless, he allocated the human mind to the background in favor of the Logos. The Logos is not merely the

sibi et talem, quails omnes uoluntates et dispensations uerbi ac sapientiae indeclinabiliter posset implore"; ibidem, SCh 268, 410: "cum uerbo Dei inmaculata foederatione coniuncta est et per hoc sola omnium animarum peccati incapax fuit, quia filii dei bene et plene capax fuit".

${ }^{53}$ Cf. ibidem, SCh 268, 410. See Grillmeier, Christ in Christian Tradition, I, p. 147.

${ }^{54}$ Cf. Crouzel, Orygenes, p. 239-241; Frend, The Rise of the Monophysite Movement, p. 107.

${ }^{55} \mathrm{Cf}$. Frend, The Rise of the Monophysite Movement, p. 107.

${ }^{56}$ Cf. Concilium Nicaenum I (325), Expositio fidei CCCXVIII patrum, ed. N.P. Tanner, in:

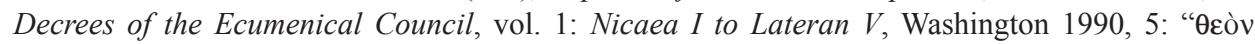

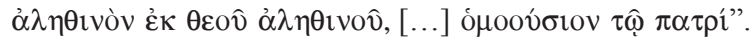

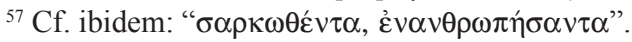

${ }^{58}$ Cf. Frend, The Rise of the Monophysite Movement, p. 109-110; Kelly, Early Christian Doctrines, p. 281-282.

${ }^{59}$ Cf. Athanasius Alexandrinus, Tomus ad Antiochenos 7, PG 26, 804B-C. See Sesboüé, Treść tradycji, p. 312-313. 
governing part of Christ's humanity, but also the real physical source of all the actions of his life ${ }^{60}$. The Logos physically moved the flesh as an instrument ${ }^{61}$.

For Athanasius, the Logos is the volitional and active principle in Christ ${ }^{62}$. Consequently, the properties of both natures are operated by one subject

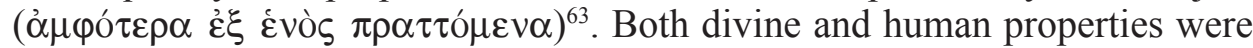
performed in communion with each other and there was One who performed them $^{64}$. Christ as God operated in divine mode but by the means of the human body as an instrument. As a human being he operated the human things. On account of the effects of Christ's operation there are seen his twofold being - divine and human ${ }^{65}$.

The humanity of Christ as an instrument thus is passive and the human soul seems not to have theological significance ${ }^{66}$. In the description of Christ's suffering in Gethsemane Athanasius presents Christ as God who wills and as a man who has a fear of flesh on account of which the divine will was commingled with human weakness ${ }^{67}$. The archbishop of Alexandria emphasized neither human soul nor human will in Christ. Athanasius seems to think of a single volition and operation having its roots in the unity of the Logos and $\operatorname{man}^{68}$.

It is noteworthy that Athanasius made distinction of the human sphere of operation in the whole operation of Christ. The human experiences like hunger, thirst, suffering and toil he ascribes to the properties of the body. He puts them at the same level as the operations of divinity like raising the dead and healing the infirm ${ }^{69}$. Athanasius' problem is that he could not solve the question concerning the subject of Christ's human experiences and sufferings. Archbishop as an adherent of Nicaea could not accept that the Logos was a subject of

${ }^{60}$ Cf. Athanasius Alexandrinus, De incarnatione Verbi 17, PG 25, 125B-D. See Grillmeier, Christ in Christian Traditio, I, p. 312; Kelly, Early Christian Doctrines, p. 285-296.

${ }^{61}$ Cf. Athanasius Alexandrinus, De incarnatione Verbi 44, PG 25, 173C. See Grillmeier, Christ in Christian Tradition, I, p. 318.

${ }^{62}$ Cf. Athanasius Alexandrinus, Orationes contra Arianos III 57, PG 26, 444B-C. See Frend, The Rise of the Monophysite Movement, p. 113; Grillmeier, Christ in Christian Tradition, I, p. 313.

${ }^{63}$ Cf. Athanasius Alexandrinus, Orationes contra Arianos III 35, PG 26, 397B-C. See Kelly, Early Christian Doctrines, p. 286-287.

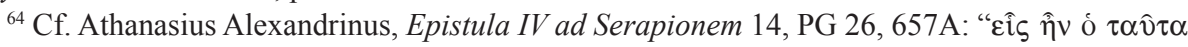

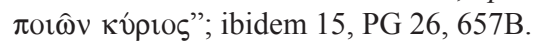

${ }^{65}$ Cf. idem, Orationes contra Arianos III 35, PG 26, 397B-C. See Kelly, Early Christian Doctrines, p. 286-287.

${ }^{66}$ Cf. Sesboüé, Treść tradycji, p. 310; Kelly, Early Christian Doctrines, p. 288.

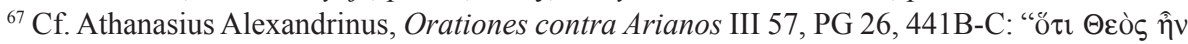

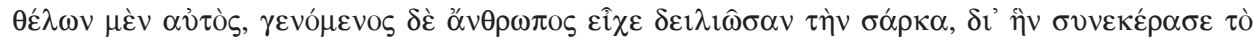

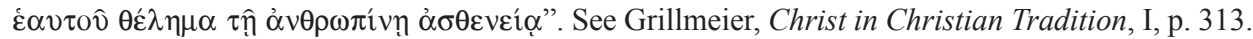

${ }^{68}$ Cf. A. Harnack, History of Dogma, transl. into English N. Buchanan, vol. 4, Boston 1898, 253.

${ }^{69} \mathrm{Cf}$. Athanasius Alexandrinus, Orationes contra Arianos III 31, PG 26, 389A-B; idem, Epistula IV ad Serapionem 14, PG 26, 656C; idem, De incarnatione contra Apollinarium II 18, PG 26, 1164B-C. 
such experiences ${ }^{70}$. This question remained unsolved. Athanasius following anthropology of Clemens of Alexandria seems to accept human lower soul of Christ, but he does not point to the activity of human mind in Christ. Such approach deepened the problem concerning the most characteristic elements of Christ's humanity, namely mind and volition. While supporting of passiveness of Christ's humanity Athanasius is a follower of Clemens and Origen and the forerunner of Apollinarius and Cyril ${ }^{71}$.

Apollinarius of Laodicea (310-390) was searching for a compromise between the consubstantial and the humanity of Christ. He taught that the incarnate Christ was a composite unity of impassible divinity and passible flesh in a human form, fused into a single nature ${ }^{72}$. Consequently, there is one incarnate nature of the $\operatorname{Logos}^{73}$. In this unity Christ is consubstantial with God according to spirit but not according to the flesh ${ }^{74}$.

The unity of nature was not compatible with the presence of human mind in $\mathrm{Christ}^{75}$. Apollinarius was convinced that the Christ's human mind would have meant a presence of human free will and ability to $\sin ^{76}$. It is impossible for the two minds bestowed with will to coexist in the same subject, because they could oppose to each other ${ }^{77}$. The Logos himself then was incarnate mind

${ }^{70}$ Cf. Grillmeier, Christ in Christian Tradition, I, p. 314.

${ }^{71} \mathrm{Cf}$. Frend, The Rise of the Monophysite Movement, p. 113.

${ }^{72}$ Cf. Apollinarius, Epistula ad Dionysium A6, ed. H. Lietzmann, in: Apollinaris von Laodicea und Seine Schule. Texte und Untersuchungen, vol. 1, Tübingen 1904 (forward - Lietzmann), 258-

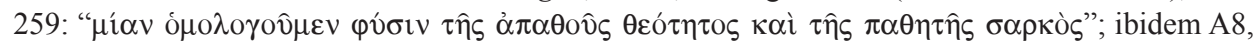

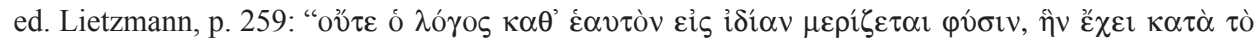

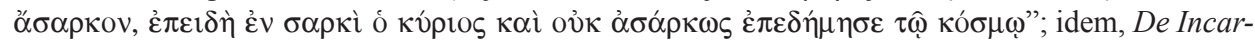

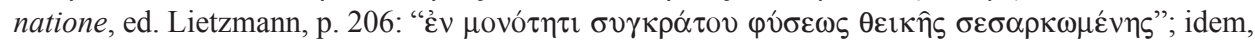

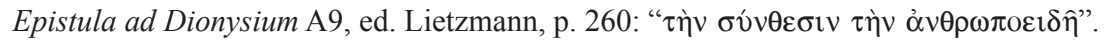

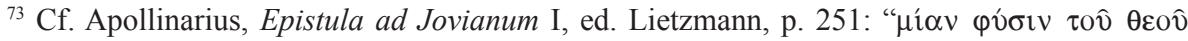

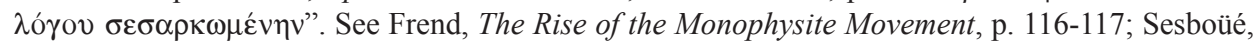
Treść tradycji, p. 317; Kelly, Early Christian Doctrines, p. 291 and 293.

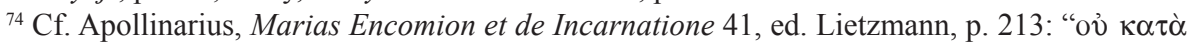

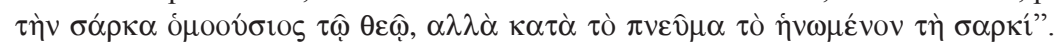

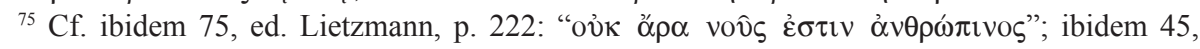

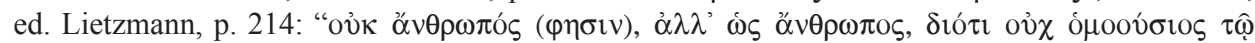

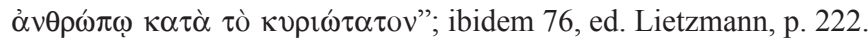

${ }^{76}$ Cf. Doctrina Patrum de Incarnatione Verbi, ed. F. Diekamp, Münster 1907, 307, 10-17. See Frend, The Rise of the Monophysite Movement, p. 13 and 116; Sesboüé, Treść tradycji, p. 315-316.

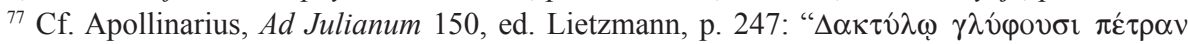

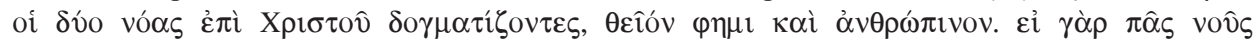

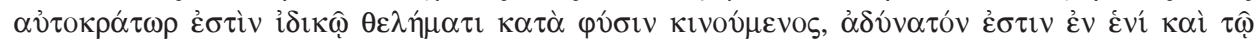

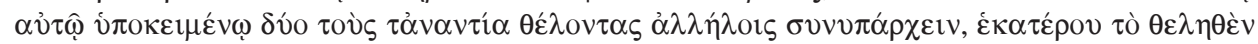

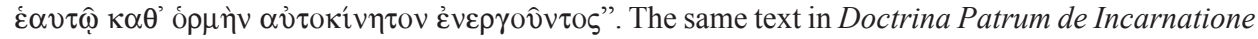
Verbi, ed. Diekamp, p. 307, 4-9. See Sesboüé, Treść tradycji, p. 315-316; Grillmeier, Christ in Christian Tradition, I, p. 339; Frend, The Rise of the Monophysite Movement, p. 116. 


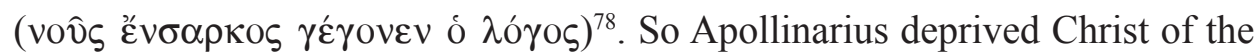
most characteristic element of humanity, the mind ${ }^{79}$. Accordingly, Christ's humanity was deprived of its own operation $(\dot{\varepsilon} \vee \varepsilon \dot{\varepsilon} \rho \gamma \varepsilon 1 \alpha)^{80}$ and will $(\theta \dot{\varepsilon} \lambda \eta \mu \alpha)^{81}$.

In this model of Christology humanity of Christ was a mere instrument (óp $\gamma \alpha v o v)$ of the $\operatorname{Logos}^{82}$. According to Apollinarius the humanity $(\sigma \hat{\omega} \mu \alpha)$ cannot be titled as a nature ( $\varphi v 01 \varsigma$ ), since this term can only be applied to element which is life-giving ( $\zeta \omega 0 \pi$ oròv). The humanity of Christ cannot be separated from the life-giving $\operatorname{Logos}^{83}$, so the humanity itself is not life-giving. The Logos thus was not only the intelligent and volitional principle in Jesus Christ but also the vivifying principle of his flesh ${ }^{84}$.

As being one, Christ had one will as He had one operation which proceeds from the single nature ${ }^{85}$. One operation is guarantee of unity of $\mathrm{Christ}^{86}$ : he was one nature, one hypostasis, one operation, one person, at once wholly God and wholly man $^{87}$. Aloys Grillmeier (1910-1998) acknowledges that the Apollinarian system as a miaenergetic or miatheletic creation had great influence in this form and devalued the human soul of Christ wherever the Logos-sarx model was propagated ${ }^{88}$.

It is noteworthy that there was also a new trend in Alexandrian Christology which emphasized the full reality of Christ's humanity. This trend was

${ }^{78}$ Cf. Apollinarius, Marias Encomion et de Incarnatione 70-71, ed. Lietzmann, p. 220-221. See Grillmeier, Christ in Christian Tradition, I, p. 333.

${ }^{79} \mathrm{Cf}$. Frend, The Rise of the Monophysite Movement, p. 117-118.

${ }^{80}$ Cf. Apollinarius, Marias Encomion et de Incarnatione 59, ed. Lietzmann, p. 217-218:

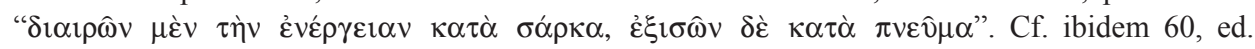
Lietzmann, p. 218.

${ }^{81}$ Apollinarius makes allusion to the prayer in Gethsemane. Cf. idem, In Epifania 109, ed.

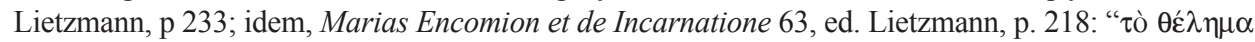

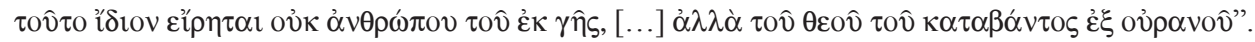

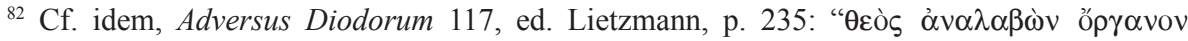

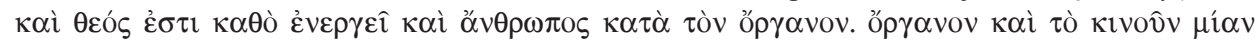

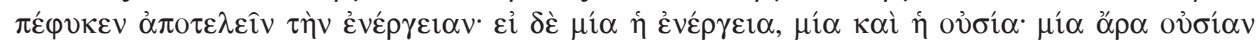

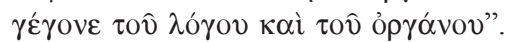

${ }^{83}$ Cf. idem, Epistula ad Dionysium A8, ed. Lietzmann, p. 259. See Grillmeier, Christ in Christian Tradition, I, p. 334.

${ }^{84}$ Cf. Kelly, Early Christian Doctrines, p. 292.

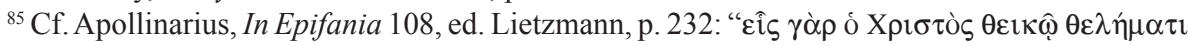

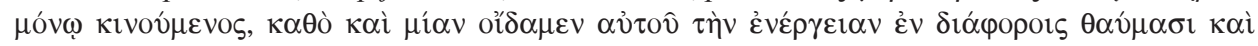

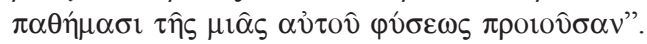

${ }^{86}$ Cf. Doctrina Patrum de Incarnatione Verbi, ed. Diekamp, p. 307, 17-20: " $\delta$ '

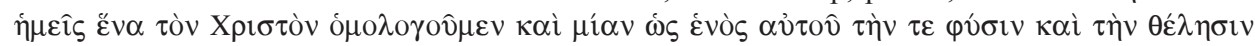

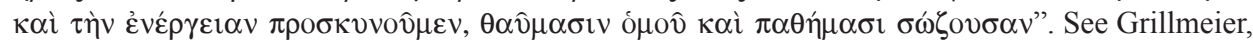
Christ in Christian Tradition, I, p. 336.

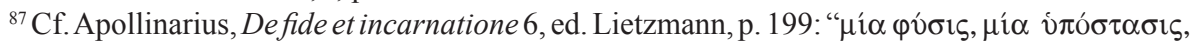

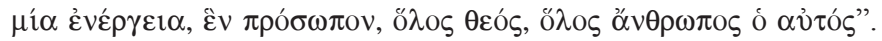

${ }^{88}$ Cf. Grillmeier, Christ in Christian Tradition, I, p. 339, 342 and 346. 
represented by Didymus of Alexandria (c. 313-398) ${ }^{89}$. He considers the soul of Christ as a principle of his human activity ${ }^{90}$. Christ's human spirit is of the

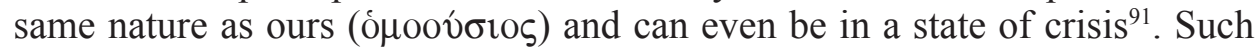
picture of Christ was not dominant in the fourth century in Alexandria, but nevertheless it had influence on Christological teaching in Antiochia.

Cyril of Alexandria (c. 376-444) returned to the Athanasian model of Logos-sarx Christology. It should be noted that Cyril formed his views under the great influence of Apollinarius while not knowing about that. Apollinarius' works under the names of orthodox theologians provided Cyril with much of his fundamental ideas ${ }^{92}$.

Cyril teaches the two aspects of Christ's being - divine and human ${ }^{93}$. Christ was formed as a unity of two natures. He was consubstantial with God according to divinity and consubstantial with human beings according to humanity ${ }^{94}$. The archbishop of Alexandria believed in the full humanity of Christ; his flesh was ensouled by the reasonable soul ${ }^{95}$.

Cyril's Christology seems to follow Apollinarius in the understanding of the meaning of the term nature ( $\varphi v 0 ı \varsigma$ ). In Antioch at that time this term meant a concrete assemblage of characteristics or attributes. In Alexandria, as we saw in Apollinarius, pv́бıs meant a concrete individual or independent existence.

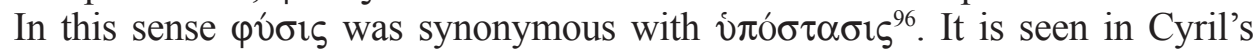
teaching that the nature or hypostasis which was the Logos, became incarnate. Consequently, there came to be one incarnate nature of the divine Logos ${ }^{97}$. The Lord's humanity became a concrete existent reality in the nature or hypostasis of

${ }^{89}$ Cf. ibidem, p. 361.

${ }^{90}$ Cf. Pseudo-Didymus, De Trinitate 3, 21, PG 39, 904A-B. See Grillmeier, Christ in Christian Tradition, I, p. 362; Frend, The Rise of the Monophysite Movement, p. 119-120.

${ }^{91}$ Cf. Grillmeier, Christ in Christian Tradition, I, p. 363.

${ }^{92}$ Cf. Frend, The Rise of the Monophysite Movement, p. 120-121; P. Rorem - J.C. Lamoreaux, John of Scythopolis on Apollinarian Christology and the Pseudo-Areopagite's True Identity, ChH 62 (1993) fasc. 4, 476.

${ }^{93}$ Cf. Kelly, Early Christian Doctrines, p. 319. See Cyrillus Alexandrinus, Apologeticus contra

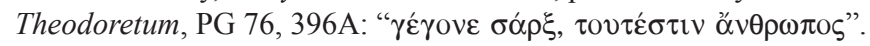

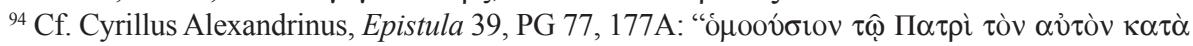

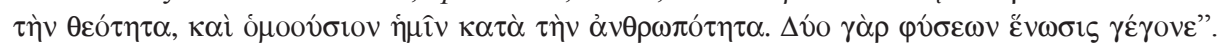

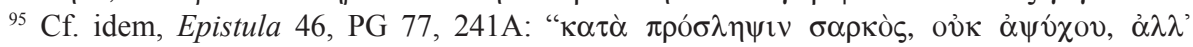

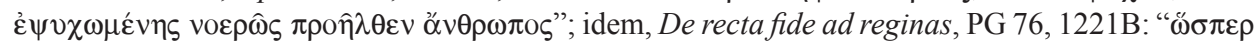

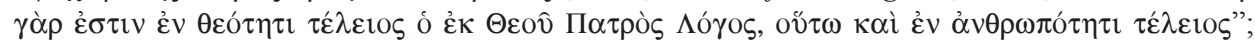
idem, Epistula 45, PG 77, 232A-B; idem, Epistula 44, PG 77, 225D; idem. Apologeticus contra Theodoretum, PG 76, 401B. See Grillmeier, Christ in Christian Tradition, I, p. 415; Kelly, Early Christian Doctrines, p. 320; Sesboüé, Treść tradycji, p. 332; Frend, The Rise of the Monophysite Movement, p. 121.

${ }^{96}$ For Antiochean "nature" Cyril preferred another phrases like "natural property", "manner of being" or "natural quality", cf. Kelly, Early Christian Doctrines, p. 318-319.

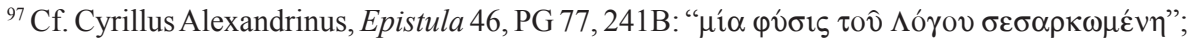

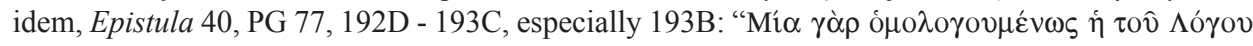


the Logos ${ }^{98}$. Cyril's concept of $\varphi v ́ \sigma ı \varsigma$ thus contains not only the idea of a simple

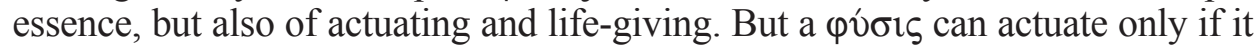
is a hypostasis, that is a real substance and a ground of existence ${ }^{99}$. The unity of Christ was then actuated in hypostasis of the Logos, so there is just one subject ${ }^{100}$.

As a result of the most fundamental union each of the natures participated in the properties of the other ${ }^{101}$. Cyril taught the communicatio idiomatum ${ }^{102}$. But there was no alteration, confusion or mixture neither in the Logos nor in the humanity ${ }^{103}$. For an illustration of this belief Cyril appealed to the live coal of Isaiah's vision. When the charcoal was penetrated by the fire, both the coal and the fire retained its identity ${ }^{104}$. His known analogy is also that of the union of the human soul and the body ${ }^{105}$.

Cyril seems to consider reasonable soul of Christ as a subject of human experiences and sufferings ${ }^{106}$. It was the soul that played the decisive part in his act of obedience ${ }^{107}$. Cyril argues that in theory we can distinguish two operations - divine and human. The principle ( $\lambda$ ó $\gamma \circ \varsigma$ ) of manner of being in Christ implies the principle of operation ${ }^{108}$. The God and the creature cannot have the same natural operation in order that the creature was not adduced to divine essence and the divinity was not reduced to the creature ${ }^{109}$. The divine operation befits only to $\mathrm{God}^{110}$. The same kind of operation thus leads to the same kind of essence and, contrary, the different kind of essence implies the different kind of operation ${ }^{111}$. The same kind of operation is also bound to the same kind of reason $\left(\lambda \circ \text { ó }_{0}\right)^{112}$.

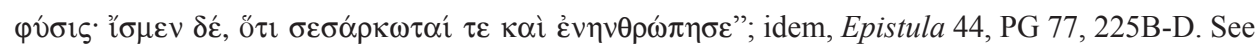
Kelly, Early Christian Doctrines, p. 319.

${ }^{98}$ Cf. Cyrillus Alexandrinus, Apologeticus contra Theodoretum, PG 76, 401A-B.

${ }^{99}$ Cf. Grillmeier, Christ in Christian Tradition, I, p. 481.

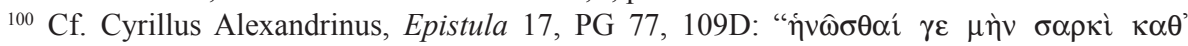

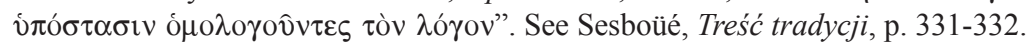

${ }^{101}$ Cf. Cyrillus Alexandrinus, De incarnatione Unigeniti, PG 75, 1244B.

${ }^{102} \mathrm{Cf}$. idem, Epistula 46, PG 77, 241B.

${ }^{103}$ Cf. idem, Epistula 44, PG 77, 225B-C; idem, Epistula 45 PG, 77, 232A-D.

${ }^{104} \mathrm{Cf}$. idem, Scholia de incarnatione Unigeniti 9, PG 75, 1380A-B.

${ }^{105}$ Cf. idem, Quod unus sit Christus, PG 75, 1292A-B; idem, Epistula 46, PG 77, $241 \mathrm{~B}$.

${ }^{106}$ Cf. idem, Scholia de incarnatione Unigeniti 8, PG 75, 1376C - 1377C; idem, Ad reginas de recta fide oratio altera, PG 76, 1413A-C; idem, Epistula 46, PG 77, 240C-D. See Grillmeier, Christ in Christian Tradition, I, p. 475-476; Frend, The Rise of the Monophysite Movement, p. 124; Kelly, Early Christian Doctrines, p. 323.

${ }^{107}$ Cf. Cyrillus Alexandrinus, Scholia de incarnatione Unigeniti 8, PG 75, 1376C - 1377C. See Kelly, Early Christian Doctrines, p. 323; Sesboüé, Treść tradycji, p. 346.

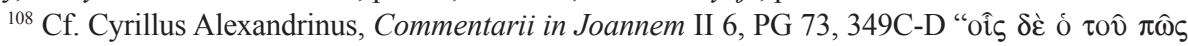

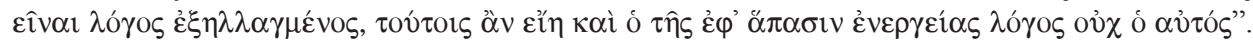

${ }^{109}$ Cf. idem, Thesaurus 32, PG 75, 453B-C.

${ }^{110}$ Cf. idem, Commentarii in Joannem III 1, PG 73, 409A-B.

${ }^{111}$ Cf. idem, Thesaurus 8, PG 75, 105A-B; 10, PG 75, 137A-B; 14, PG 75, $241 \mathrm{~B}$.

${ }_{112}$ Cf. ibidem 34, PG 75, 605D; 32, PG 75, 453C, 517D and 557A; idem, De Trinitate dialogi 3, PG 75, 797D. 
In practice, however, Cyril shows that there is a single operation ( $\mu$ í $\alpha \nu \tau \varepsilon$

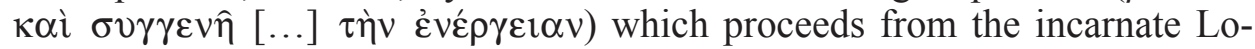
gos. This point is evident in his commentary on the rising of the daughter of the leader of Synangogue (Mk 5:35-37; Lk 7:49-56) and of a young boy (Lk 7:13-17 $)^{113}$. Christ operated at the same time divinely and humanly as one subject ${ }^{114}$. The Logos and flesh thus combine in their activity into a single kind of operation. Cyril taught that the Logos imparted the glory of the divine operation to his own flesh ${ }^{115}$, therefore also the body itself was life-giving ${ }^{116}$. For an illustration of this belief Cyril appealed to the analogy of the combine energy of fire and red-hot iron where both perform the same operation but retain their identity ${ }^{117}$. Accordingly, Cyril points to one will of the Father and the incarnate

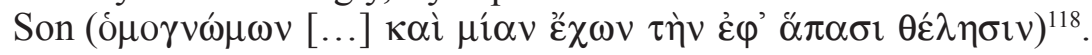

Although Cyril of Alexandria considered $\sigma \alpha \dot{\alpha} \rho \xi$ as a fullness of human being ${ }^{119}$, the role of the human soul was receeded into the background. The properties of the human soul of Christ were subordinate to the Logos and the Logos has imparted its properties to humanity. The theological significance of Christ's human soul and its operation were not clearly emphasized, though not denied. Accordingly, Cyril created a subject of Christ's activity which has common human and divine characteristics.

Alexandrian Logos-sarx type of Christology highly influenced the Christological reflection of the Eastern theologians ${ }^{120}$. It is probable that the fourth letter of Pseudo-Dionysius the Areopagite (late V - early VI century) refers to the teaching and notions of Cyril when he speaks of a simple new divinehuman operation of Christ. Dionysius stated that Christ operated divine things not just according to divine nature and human things not just according to human nature but having become God-man he manifested to us some new

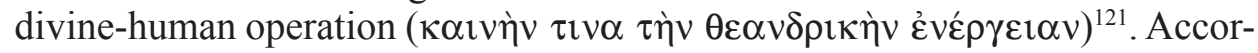

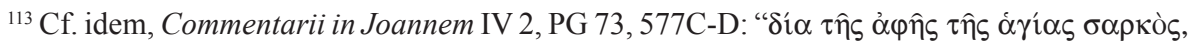

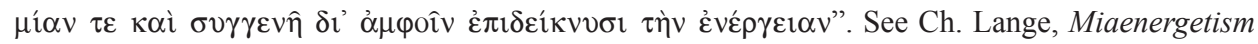
- A New Term for the History of Dogma?, StPatr 63 (2013) 329.

${ }^{114}$ Cf. Cyrillus Alexandrinus, Fragmenta in Epistulam ad Hebraeos, PG 74, 1005B: " $\pi \hat{\omega} \varsigma$ ov̉к

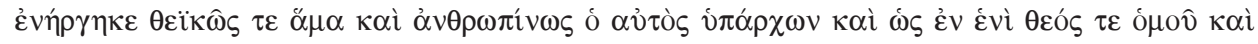

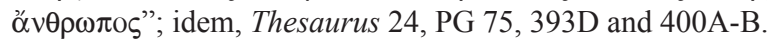

${ }^{115}$ Cf. idem, De incarnatione Unigeniti, PG 75, 1241B-C; idem, Commentarii in Joannem IV 2 , PG 73, 577C-D; XII, PG 74, 724B - 729C.

${ }^{116}$ Cf. idem, Commentarii in Joannem IV 2-3, PG 73, 576C - 596C. See Grillmeier, Christ in Christian Tradition, I, p. 476.

${ }^{117}$ Cf. Cyrillus Alexandrinus, Commentarii in Joannem IV 3, PG 73, 592A.

${ }^{118}$ Cf. ibidem II 6, PG 73, 349C-D.

${ }^{119}$ Cf. Sesboüé, Treść tradycji, p. 316-317; Frend, The Rise of the Monophysite Movement, p. 113.

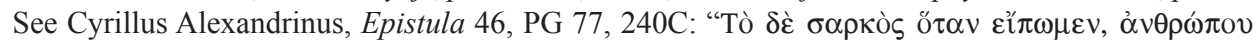

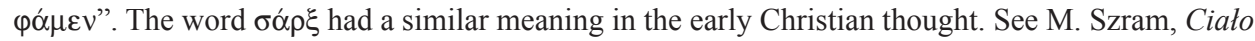
zmartwychwstałe w myśli patrystycznej przełomu II i III wieku, Lublin 2010, 167-193.

${ }^{120}$ Cf. Grillmeier, Christ in Christian Tradition, I, p. 133.

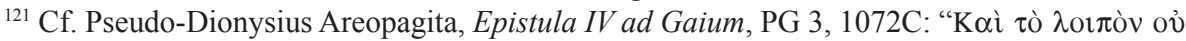


ding to Dionysius Christ operated human things above the human nature ${ }^{122}$. The Logos executed and suffered whatever things are chosen and pre-eminent in His human work of God ${ }^{123}$. Pseudo-Dionysius thus pointed to some new subject of activity in Christ, which is neither wholly divine nor merely human, but human and divine at the same time. Nevertheless, such an approach has its difficulty in explanation of Christ's human experiences and sufferings.

\section{Christology of Ephesus and Chalcedon as an acknowledgement of} Christ's humanity. The Alexandrian type of Christology is different to that of Antioch where the Logos-anthropos model prevailed. The common feature of the adherents of the Antiochian School, such as Theodore of Mopsuestia (350-428) and Nestorius (386-451), is that they acknowledged the theological significance of Christ's human soul and, consequently, of his humanity ${ }^{124}$. Nevertheless, they

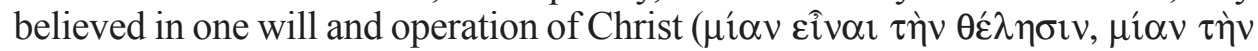

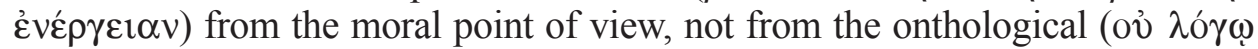
$\varphi v \tilde{\sigma \varepsilon \omega \varsigma}, \dot{\alpha} \lambda \lambda^{\prime} \varepsilon \dot{\delta} \delta$ oki $\left.\alpha \varsigma\right)^{125}$. The view of Antiochians was that the human nature was united to the Logos by the sameness of judgment ( $\tau \alpha v \tau$ tó $\eta \tau \imath ~ \gamma \nu \omega ́ \mu \eta \varsigma)$ on account of which there was also the same operation ${ }^{126}$.

As a result of polemics between Cyril and Nestorius (c. 386 - c. 450) there was stressed the unity of subject in Christ and the truth of His humanity at the Council of Ephesus (431). Formula of Reunion of 433 upheld that Christ was

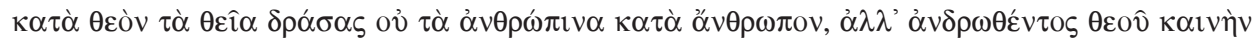

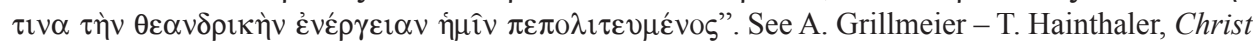
in Christian Tradition, vol. 2: From the Council of Chalcedon (451) to Gregory the Great (590-604), part 2: The Church of Constantinople in the Sixth Century, transl. into English P. Allen - J. Cawte, London 1995, 170 and 225; Harnack History of Dogma, IV, p. 236.

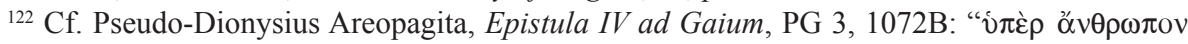

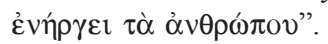

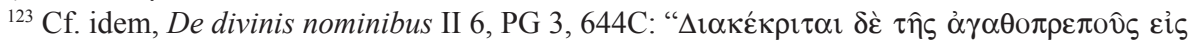

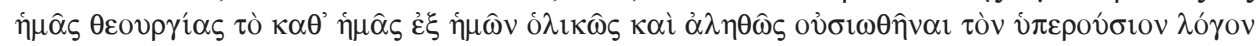

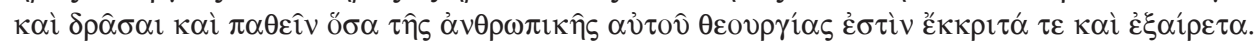

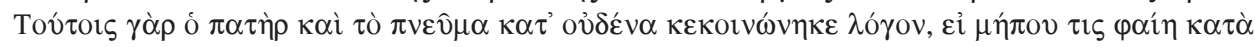

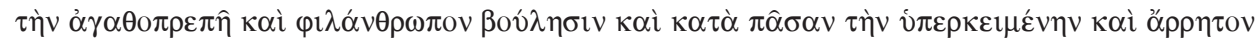

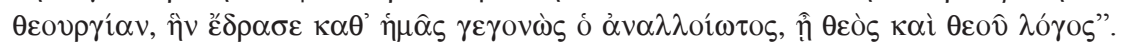

${ }^{124}$ Cf. Kelly, Early Christian Doctrines, p. 302.

${ }^{125}$ Cf. Theodorus Mopsuestenus, Fragmentum in Matthaeum PG 66, 1004D; Nestorius, Fragmenta, ed. F. Loofs, in: Nestoriana: Die Fragmente Des Nestorius, Halle 1905, 224, 12-15: “O ̌̌

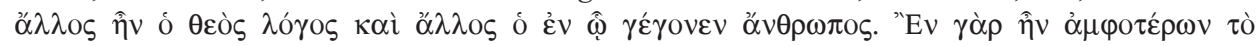

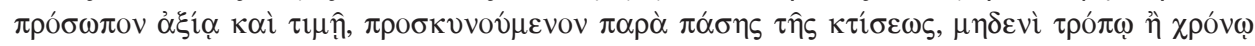

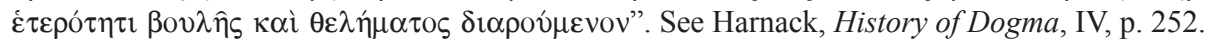

${ }^{126}$ Cf. Theodorus Mopsuestenus, De Incarnatione, in: Concilium Lateranense a. 649 celebra-

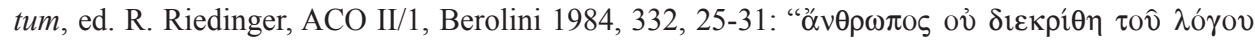

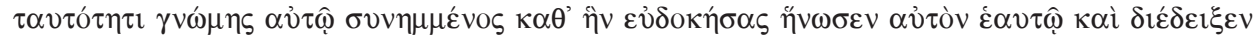

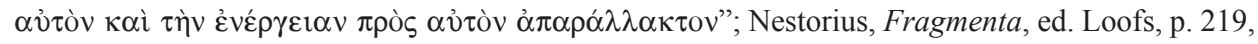

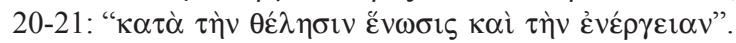


a real man with reasonable soul and real flesh. Christ was defined as "consubstantial with the Father according to divinity and with us according to humanity". The $\mu i \alpha \alpha$ pvi

Although during the period from Ephesus to Chalcedon (431-451) the fullness of divinity and humanity in Christ were acknowledged by majority, there arose other aspects of Christology, namely the discussion concerning the manner of union, its consequences for the humanity of Christ and the relationship between the human and divine elements within Christ ${ }^{128}$.

The main stream of Christology was directed towards acknowledgment of the single hypostasis and the two natures of the incarnate Logos ${ }^{129}$. That question was solved by Chalcedon (451). The model of Chalcedon's definition was Formula of Reunion of 433. Chalcedon teaches that Christ is both perfect God and perfect man with flesh and reasonable soul. The properties of the na-

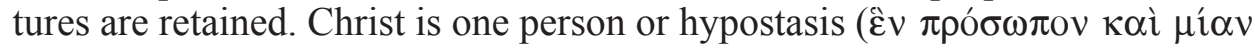

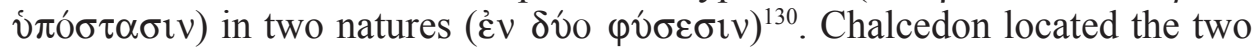
natures in their closeness to each other as if the two realities were of the same ranking ${ }^{131}$. The in two natures formula became in the West the touchstone of orthodoxy. It emphasized the reality of Christ's humanity ${ }^{132}$. Concerning the question of operations Chalcedon through the Tome of $\mathrm{Leo}^{133}$ sanctioned the two operations in Christ. According to Leo each nature operates its property ${ }^{134}$.

${ }^{127}$ Cf. Concilium Ephesinum (431), Formula unionis, ed. N.P. Tanner, in: Decrees of the Ecu-

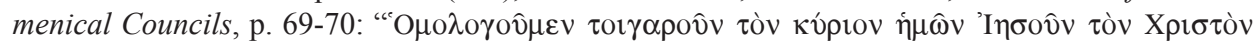

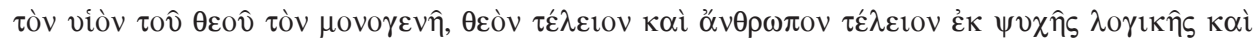

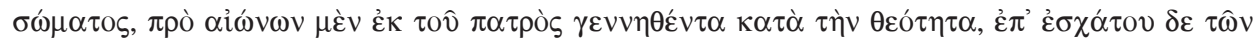

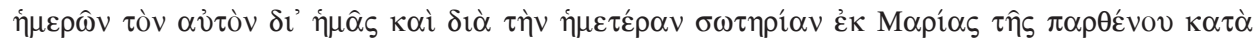

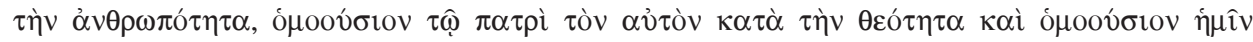

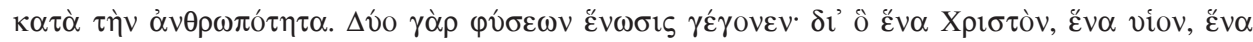

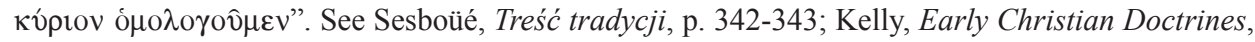
p. 328-329; Frend, The Rise of the Monophysite Movement, p. 21-22.

${ }^{128}$ Cf. Grillmeier, Christ in Christian Tradition, I, p. 445; Sesboüé, Treść tradycji, p. 345; Frend, The Rise of the Monophysite Movement, p. 12 and 104.

${ }^{129} \mathrm{Cf}$. Liberatus Diaconus, Breviarium causae Nestorianorum et Eutychianorum IX-XI, PL 62, 986A - 1002A. See Frend, The Rise of the Monophysite Movement, p. 22-23.

${ }^{130}$ Cf. Concilium Chalcedonense (451), Definitio fidei, ed. N.P. Tanner, in: Decrees of the Ecu-

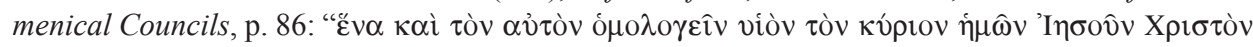

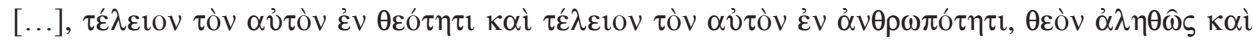

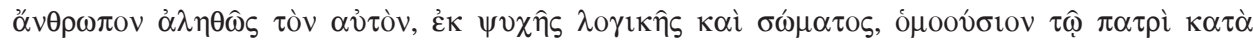

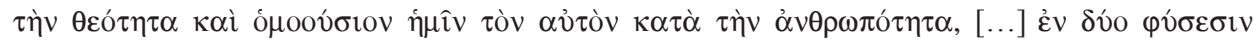

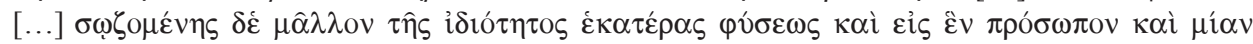

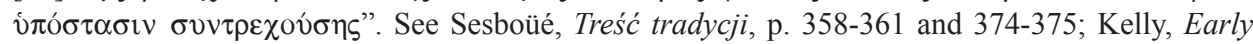
Christian Doctrines, p. 339-340; Frend, The Rise of the Monophysite Movement, p. 47.

${ }^{131}$ Cf. Sesboüé, Treść tradycji, p. 362.

${ }^{132}$ Cf. Frend, The Rise of the Monophysite Movement, p. 5 and 49.

${ }^{133}$ Cf. Concilium Chalcedonense (451), Definitio fidei, ed. Tanner, p. 85.

${ }^{134}$ Cf. Leo Magnus, Epistula ad Flavianum ep. Constantinopolitanum de Eutyche, ed. N.P. Tanner, in: Decrees of the Ecumenical Councils, p.79: "Agit enim utraque forma cum alterius commu- 
The Council of Chalcedon opened the doors to the further discussions. The Council did not achieve complete unity of thought, as a consensus concerning the theological phrasing was not achieved ${ }^{135}$. Adolf Harnack (1851-1930) stated that in the Chalcedonian formula a foreign power had imposed itself on the Church of the East ${ }^{136}$. The most discussed aspect of the Formula in the next years was to be not only the fullness of Christ's humanity, but also the relationship between the natures and activity in $\mathrm{Christ}^{137}$. The main focus of the theological discussion of the sixth century was thus shifted from the problem of unity in Christ to its expression.

4. Anti-Chalcedonian reaction as a returning to Cyril. The Council of Chalcedon was definitely acknowledged by the Church of Latin West and majority of the Church of the Patriarchate of Constantinople and of Jerusalem. Almost half of the Patriarchate of Antioch claimed loyalty to Chalcedon. The majority of the Church in Egypt had refused to accept the Council ${ }^{138}$. In the eyes of opponents Tome of Leo and the Council seemed to consecrate the doctrine of Nestorius while condemning him by name. Chalcedon was opposed on the ground that there could only be one reality or nature of Christ, namely the divine nature. He could be out of two natures but not in two natures. This movement of opposition to Chalcedon had become known as Monophysitism ${ }^{139}$. Its adherents were strictly bound to the language of Cyril ${ }^{140}$. It should be noted that there were the two leading groups in the anti-Chalcedonian camp which differed in their view on the fullness of Christ's humanity. The one asserted that Christ humanity was perfect and consubstantial with ours; the other denied the idea of Christ's consubstantiality with human beings ${ }^{141}$. Not all the Monophysites thus were monophysites by conviction.

The majority of Monophysites were ready to come to union with pro-Chalcedonians, because they really strictly maintained the Christology of Cyril ${ }^{142}$.

nione quod proprium est, verbo scilicet operante quod Verbi est, et carne exequente quod carnis est. Unum horum coruscate miraculis, alius subcumbit iniuriis".

${ }^{135}$ Cf. Sesboüé, Treść tradycji, p. 363-364; Harnack, History of Dogma, IV, p. 237.

${ }^{136}$ Cf. Harnack, History of Dogma, IV, p. 240.

${ }^{137}$ Cf. P.T.R. Gray, Introduction, in: Leontius of Jerusalem. Against the Monophysites: Testimonies of the Saints and Aporiae, ed. and transl. P.T.R. Gray, Oxford 2006, 32; Th. Cattoi, An Evagrian iлó $\sigma \tau \alpha \sigma \mathrm{\iota}$ ? Leontios of Byzantium and the 'Composite Subjectivity' of the person of Christ, StPatr 68 (2011) 139; Sesboüé, Treść tradycji, p. 362.

${ }^{138}$ Cf. Gray, Introduction, p. 5; Grillmeier - Hainthaler, Christ in Christian Tradition, II/2, p. 1;

Frend, The Rise of the Monophysite Movement, p. 136-142; Sesboüé, Treść tradycji, p. 363-364.

${ }^{139}$ Cf. Frend, The Rise of the Monophysite Movement, p. X, p. 6 and 136-142.

${ }^{140}$ Cf. Sesboüé, Treść tradycji, p. 363-364.

${ }^{141}$ Cf. Lange, Miaenergetism, p. 327-328; Grillmeier - Hainthaler, Christ in Christian Tradition, II/2, p. 21.

${ }^{142}$ Cf. Frend, The Rise of the Monophysite Movement, p. 318-319. 
This position was supported by the most important champion of the Monophysitism - Severus of Antioch (465-538, patriarch 512-518) ${ }^{143}$.

Severus states that the Son was united to flesh which had a soul filled with reason and intelligence. Christ is out of two natures and not in two natures ${ }^{144}$. Although Christ is out of two realities only the Logos has the nature in the full meaning of the word $\varphi v 0 r \varsigma^{145}$. The humanity in Christ has no independent status ${ }^{146}$. Severus confesses one divine-human nature and hypostasis and one incarnate nature of the God the Logos ${ }^{147}$. There is only one Christ, one person, one hypostasis, and one nature, that of the incarnate Logos ${ }^{148}$. For Severus Chalcedonian definition that the two natures inseparably united with each other retain its own properties was nonsense ${ }^{149}$.

In spite of unity both realities of Christ's person have remained unchanged and complete. Christ is consubstantial with the Father in respect of Divinity and consubstantial with human beings in respect of humanity ${ }^{150}$. The humanity was touched by suffering ${ }^{151}$. Severus, like Cyril, believed that divinity and humanity could be distinguished in theory ${ }^{152}$.

It is noteworthy that Severus acknowledges the will of human soul of Christ. He teaches that Christ possessed two wills in salutary suffering - human and divine ${ }^{153}$. Nevertheless the principle of activity is divinity. In Christ every impulse to act comes from the Logos ${ }^{154}$. Divinity mixes itself with the human activity and produces the miraculous effect. The human will of Christ thus does not need to be active. Human activity of Christ was dependent on the

${ }^{143}$ Cf. Frend, The Rise of the Monophysite Movement, p. 201 and 213; Grillmeier - Hainthaler, Christ in Christian Tradition, II/2, p. 20; Harnack, History of Dogma, IV, p. 235-236.

${ }^{144}$ Cf. Severus, Orationes ad Nephalium II, in: P. Allen - C.T.R. Hayward, Severus of Antioch, London and New York, 2004, 59-60.

${ }^{145}$ Cf. Grillmeier - Hainthaler, Christ in Christian Tradition, II/2, p. 155.

${ }^{146}$ Cf. Allen - Hayward, Severus of Antioch, p. 35.

147 Cf. Doctrina Patrum de Incarnatione Verbi, ed. Diekamp, p. 309, 24-25: " $\mu$ íav

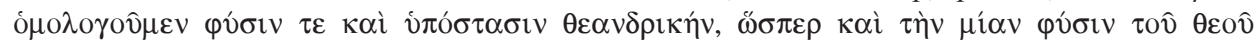

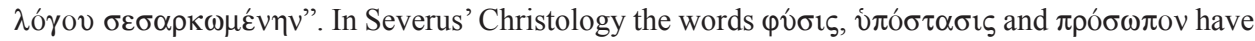
a common meaning, namely "nature". See Allen - Hayward, Severus of Antioch, p. 34; Frend, The Rise of the Monophysite Movement, p. 209.

${ }^{148}$ Cf. Frend, The Rise of the Monophysite Movement, p. 209; Allen - Hayward, Severus of Antioch, p. 86-87.

${ }^{149}$ Cf. Severus, Fragmenta, in: Allen - Hayward, Severus of Antioch, p. 76-77; ibidem, p. 6768, 70, and 74-75. See Frend, The Rise of the Monophysite Movement, p. 211.

${ }^{150}$ Cf. Severus, Fragmenta, in: Allen - Hayward, Severus of Antioch, p. 102-106, 70-73 and 82-85. See Lange, Miaenergetism, p. 327; Frend, The Rise of the Monophysite Movement, p. 209.

${ }^{151}$ Cf. Severus, Adversus apologiam Juliani 3, in: Allen - Hayward, Severus of Antioch, p. $99-101$.

${ }^{152}$ Cf. Frend, The Rise of the Monophysite Movement, p. 212.

${ }^{153}$ Cf. Grillmeier - Hainthaler, Christ in Christian Tradition, II/2, p. 167-168.

${ }^{154}$ Cf. Doctrina Patrum de Incarnatione Verbi, ed. Diekamp, p. 310, 14-19. See Grillmeier Hainthaler, Christ in Christian Tradition, II/2, p. 166. 
divinity in the whole area of willing and knowing. The humanity of Christ was transformed by the Logos not into his own nature, but into his own operation. The Logos sometimes allowed the flesh to experience that which is proper to $\mathrm{it}^{155}$. The faith in Christ as one nature out of two demands thus one subject who acts and one movement which agitates him in action, although the deeds which come from the action are different ${ }^{156}$.

Against duality of operations Severus stated, that the two operations of Leo imply the two bearing subjects $(\pi \rho \sigma \sigma \omega \pi \alpha)^{157}$. There is a two only in the result of Christ's activity, namely two different types of the effect of Christ's activity - divine and human. Severus adduces the analogy of human soul and body. In the human being there is only one process of activity which in effect produces two different types of activity, intellectual and sensible-corporeal. Likewise in Christ there is only one activity, one operative motion but the performed deeds are different ${ }^{158}$. Accordingly, Severus believes in one composite operation ( $\sigma 0 ́ v \theta \varepsilon \tau o v$

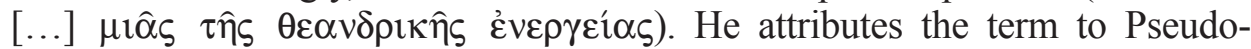
Areopagite, and thereby claimed an ancient tradition for this notion ${ }^{159}$. The one composite activity of Christ is strictly bound to the single nature and hyposta-

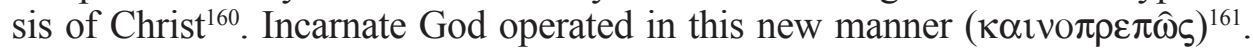
Severus like Cyril and Pseudo-Dyonysius had problems with explanation of a subject of Christ's human experiences like hunger and suffering ${ }^{162}$.

The strength of Severus' position is that his teaching was based on the thought of the great theologians as the Cappadocian Fathers and Cyril ${ }^{163}$. In

${ }^{155}$ Cf. Grillmeier - Hainthaler, Christ in Christian Tradition, II/2, p. 83-84, 162-164 and 168. Like Severus, the anti-Chalcedonian monophysite patriarch Theodosius of Alexandria (†567) underlines the need to exclude any duality in the incarnate Logos by stressing the single combined operation. He asserts that according to Severus the recusing of one operation would follow the doctrine of two natures and two operations in Christ, what is the blasphemy of Theodoret of Cyrus. See ACO II/2, 1, 382, 1-9. Cf. Lange, Miaenergetism, p. 330.

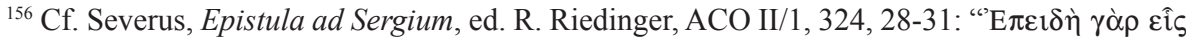

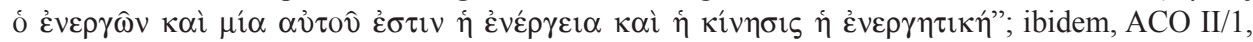
324, 33-36. See H.-J. Höln, The Preacher, in: Grillmeier - Hainthaler, Christ in Christian Tradition, II/2, p. 145-146.

${ }^{157}$ Cf. ACO II/1, 326, 1-5 and 7-14; Doctrina Patrum de Incarnatione Verbi, ed. Diekamp, p. 310, 14-19. See Grillmeier - Hainthaler, Christ in Christian Tradition, II/2, p. 166.

${ }^{158}$ Cf. Höln, The Preacher, p. 145-146; Grillmeier - Hainthaler, Christ in Christian Tradition, II/2, p. 163 and 165; Allen - Hayward, Severus of Antioch, p. 35.

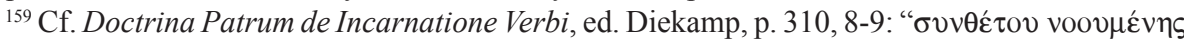

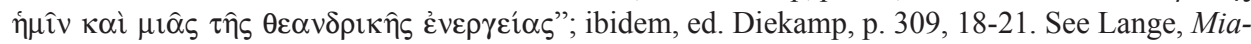
energetism, p. 330; Allen - Hayward, Severus of Antioch, p. 35.

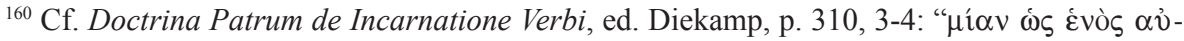

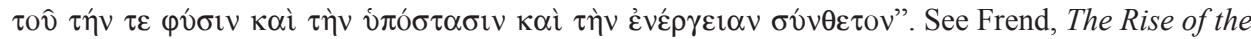
Monophysite Movement, p. 212.

${ }^{161}$ Cf. Doctrina Patrum de Incarnatione Verbi, ed. Diekamp, p. 309, 23-24.

${ }^{162}$ Cf. Grillmeier - Hainthaler, Christ in Christian Tradition, II/2, p. 171.

${ }^{163}$ Cf. Frend, The Rise of the Monophysite Movement, p. 206, 208 and 213. 
reality Severus represented orthodoxy alternative to that of Chalcedon; he just articulated another aspect of orthodoxy ${ }^{164}$. He strictly denied the supposition that he devalued the fullness of the human nature of Christ ${ }^{165}$. Moreover, he was opposed to the Eutychians and the Apollinarians ${ }^{166}$. Unfortunately, Severus was misunderstood, especially in his use of the term $\varphi v 01 \varsigma^{167}$.

\section{Pro-Chalcedonian reaction as a compromise between Cyril and} Chalcedon. In the sixth century there arose a movement called Neo-Chalcedonianism as an attempt of pro-Chalcedonians to emphasize more clearly the unity of two natures in Christ and to coincide the formula of Chalcedon with the teaching of Cyril ${ }^{168}$. It sought to make Tome of Leo and the formula of Chalcedon more acceptable to the followers of Cyril ${ }^{169}$. It was a new way of interpreting the orthodox tradition ${ }^{170}$. Neo-Chalcedonianism interpreted Chalcedon in a Cyrillian terms ${ }^{171}$ or, inversely, Cyril was interpreted in Chalcedonian terms ${ }^{172}$. The most remarkable representatives of this trend were Leontius of Byzantium (c. 485-544) $)^{173}$ and Leonius of Jerusalem ( $†$ after 544) ${ }^{174}$.

Leontius of Byzantium approached the Christological problem on the ground of a new interpretation of the notion of hypostatical union ${ }^{175}$. According to Leontius within the same Logos two manners of relation may be discerned: in one, the Logos is in a relationship of sameness with the Father

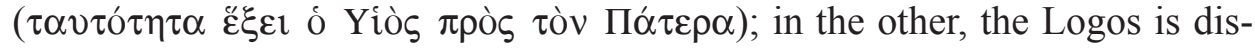

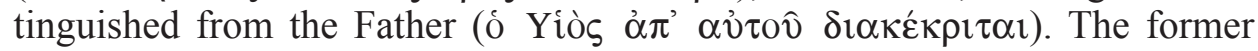
is indicated by the term $\varphi v ́ \sigma \imath \varsigma$, and the latter by the term $\tilde{\pi}$ ó $\sigma \tau \alpha \sigma \imath \varsigma^{176}$. He

${ }^{164}$ Cf. Grillmeier - Hainthaler, Christ in Christian Tradition, II/2, p. 152-173; Gray, Introduction, p. 32; S. Rees, Leontius of Byzantium and His Defence of the Council of Chalcedon, HTR 24 (1931) fasc. 2, 113.

${ }^{165}$ Cf. Harnack, History of Dogma, IV, p. 237.

${ }^{166}$ Cf. Frend, The Rise of the Monophysite Movement, p. 205-206.

${ }^{167}$ Cf. Rees, Leontius of Byzantium, p. 116.

${ }^{168}$ Cf. M. Szram, Neochalcedonizm, EK XIII 902; Gray, Introduction, p. 2.

${ }^{169} \mathrm{Cf}$. Gray, Introduction, p. 30.

${ }^{170} \mathrm{Cf}$. idem, Neo-Chalcedonianism and The Tradition: From Patristic to Byzantine Theology, ByF 8 (1982) 61.

${ }^{171}$ Cf. idem, Introduction, p. 30.

${ }^{172}$ Cf. Rees, Leontius of Byzantium, p. 118-119; Frend, The Rise of the Monophysite Movement, p. 186.

${ }^{173}$ Cf. Rees, Leontius of Byzantium, p. 111-119; J. Naumowicz, Leoncjusz z Bizancjum, EK X 794-795.

${ }^{174}$ In the past Leontius of Byzantium and of Jerusalem were confused with each other. Cf. P. Szczur, Leoncjusz z Jerozolimy, EK X 795-796. On Leontius' of Jerusalem mode of theological reflection see Gray, Introduction, p. 63-65.

${ }^{175}$ Cf. Leontius Byzantinus, Contra nestorianos et eutychianos lib. I, PG 86/1, 1301C - 1305A. See Cattoi, An Evagrian vं

${ }^{176}$ Cf. Leontius Byzantinus, Contra nestorianos et eutychianos lib. I, PG 86/1, 1288A - 1289A

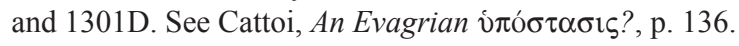


defines hypostasis as a reality which in the first place exists by itself and then perfects. Nature is a reality which does not exist by itself but perfects ( $\tau$ ò $\mu \grave{\varepsilon} v$

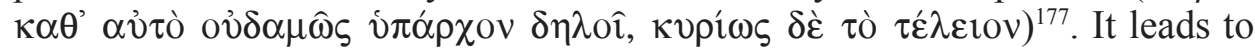
conclusion that nature is not hypostasis, but hypostasis is nature. The nature

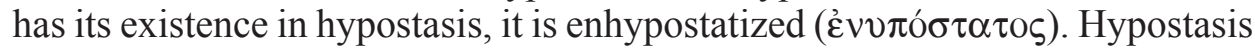
is connected with the individual, nature points to the species ${ }^{178}$. Two natures of Christ were united in the same hypostasis which was the Logos. Consequently,

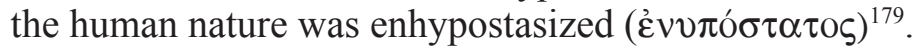

To solve the problem of Christ's human will Leontius refers to anthropology and considers volition as an act of reasonable soul ${ }^{180}$. He is convinced that Christ's natures retain their operations, since the two natures of Christ are fully preserved and their properties as well ${ }^{181}$. But through the unity with the Logos Christ was by nature incapable of corruption, mortality ${ }^{182}$ and $\sin ^{183}$. Therefore, his will did not oppose the will of the Father. Thomas Cattoi states that Leontius creates a new subject of activity which in a strict sense is neither wholly divine nor wholly human. Leontius' views in this aspect may be close to those of Cyril and Pseudo-Areopagite. His composite principle of activity seemed to be a balance between the Dyophysites and the Cyrillian miaphysites ${ }^{184}$.

Leontius of Jerusalem, like Leontius of Byzantium, was convinced that Christ's human nature is united with the divine nature in the hypostasis of the $\operatorname{Logos}{ }^{185}$. The human nature exists only in the hypostasis of the Logos. Leontius offers an analogy of the burning torch and red-hot iron. A nature of fire is begotten in addition to its original nature. Fire exists only in the hypostasis of the iron ${ }^{186}$. Concerning activity Leontius accepts a cooperation between the

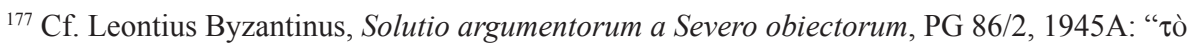

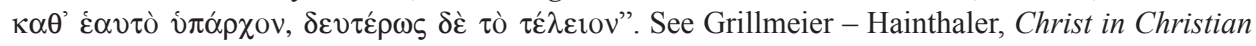
Tradition, II/2, p. 191-192.

${ }^{178}$ Cf. Leontius Byzantinus, Contra nestorianos et eutychianos lib. I, PG 86/1, 1280A:

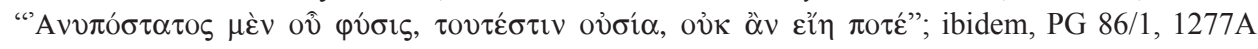
- 1280B. Grillmeier - Hainthaler, Christ in Christian Tradition, II/2, p. 190 and 194.

${ }^{179} \mathrm{Cf}$. Frend, The Rise of the Monophysite Movement, p. 278. On the theological meaning of the

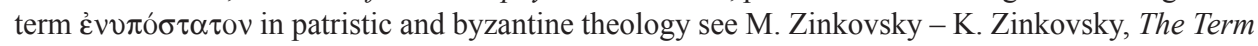

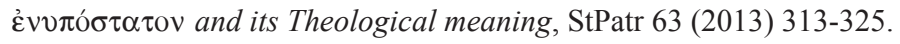

${ }^{180}$ Cf. Leontius Byzantinus, Contra nestorianos et eutychianos lib. II, PG 86/1, 1332D:

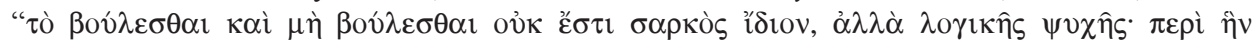

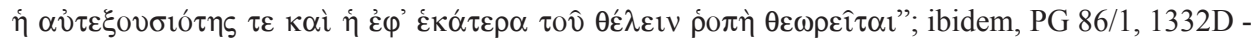
1333B. See. Grillmeier - Hainthaler, Christ in Christian Tradition, II/2, p. 223.

${ }^{181}$ Cf. Leontius Byzantinus, Contra nestorianos et eutychianos lib. II, PG 86/1, 1320A-B; ibi-

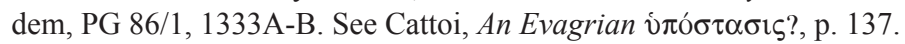

${ }^{182}$ Cf. Leontius Byzantinus, Contra nestorianos et eutychianos lib. II, PG 86/1, 1325A, 1328D

- 1329B and 1348A-C. See Grillmeier - Hainthaler, Christ in Christian Tradition, II/2, p. 225-226.

${ }^{183}$ Cf. Leontius Byzantinus, Contra nestorianos et eutychianos lib. II, PG 86/1, 1332C-D.

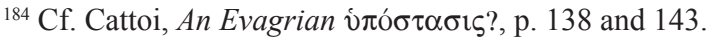

${ }^{185}$ Cf. Szczur, Leoncjusz z Jerozolimy, p. 796.

${ }^{186}$ Cf. Leontius Hierosolymitanus, Contra nestorianos II 7, PG 86/1, 1552D - 1553A. 
Logos and the human governing principle in $\mathrm{Christ}^{187}$. It is a human principle of Christ's operation ${ }^{188}$. The humanity of Christ is sinless by the fact that it is hypostatically united to divinity ${ }^{189}$. Accordingly, Christ's human operation was subordinate to the Logos.

Both Leontius of Byzantium and of Jerusalem though did not deny Christ's human volition, seem to consider it as a passive faculty in Christ's hypostasis, since it was unreservedly subordinate to the Logos on account of hypostatic unity. In this they seem to push Christ's human volition to the background. Their Christologies thus do not differ essentially from Christology of Cyril or of Severus ${ }^{190}$. Accordingly, both Leontius of Byzantium and of Jerusalem though strictly maintained Chalcedonian formula, seem to be forerunners foreshadowing the Miaenergist Christology.

6. On the eve of the Miaenergist debate. The issue of Christ's operation and will in the sixth and the seventh centuries became one of the most important questions that the orthodox Church was ever to face concerning its Christology ${ }^{191}$. The question was intensified by the necessity to find the means in order to make unity with those Monophysites who confessed the fullness of Christ's humanity. This question became the most serious stumbling-block for the adherents of Severus to find unity with pro-Chalcedonians ${ }^{192}$. There was quite a number of pro-Chalcedonian writers who rejected a single composite operation in Christ. For example, emperor Justinian (482-565, emperor $527-565)$ wrote that there are two operations of two natures in the single hy$\operatorname{postasis}^{193}$. Concurring with him, Iohannes of Scythopolis († c. 548) quoted

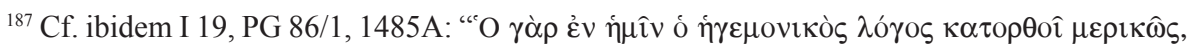

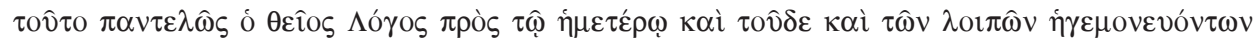

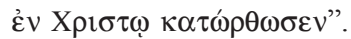

${ }^{188}$ Cf. Grillmeier - Hainthaler, Christ in Christian Tradition, II/2, p. 301.

${ }^{189}$ Cf. Leontius Hierosolymitanus, Contra nestorianos I 47, PG 86/1, 1505A-D. See Grillmeier - Hainthaler, Christ in Christian Tradition, II/2, p. 302.

${ }^{190}$ Cf. Rees, Leontius of Byzantium, p. 113. See Leontius Byzantinus, Contra nestorianos et eutychianos lib. I, PG 86/1, 1289A - 1308A.

${ }^{191}$ Cf. C. Hovorun, Will, Action and Freedom: Christological Controversies in the Seventh Century, Leiden - Boston 2008, 3. That the question of volition was not neglected in the sixth century is seen from the Miathelite florilegium. Although almost all the surviving Greek texts on the subject of the operations and the wills are of dyothelite provenance, nevertheless they make clear that the question of operations and wills was already vividly discussed in the second half of the sixth century as a significant aspect of Christology. See S. Brock, A Monothelete Florilegium in Syriac, in: S. Brock, Studies in Syriac Christianity: History, Literature and Theology, Hampshire 1992, 44.

${ }^{192}$ Cf. Lange, Miaenergetism, p. 330; Allen - Hayward, Severus of Antioch, p. 35; Harnack, History of Dogma, IV, p. 235 and 253.

${ }^{193}$ Cf. Iustinianus Imperator, Adversus Nestorianos et Acephalos, ed. R. Riedinger, in: Concilium Universale Constantinopolitanum Tertium (680-681), ACO II/2, 1, Berolini 1990, Actio 10, 350, 6 - 352, 10. See Lange, Miaenergetism, p. 332; Grillmeier - Hainthaler, Christ in Christian Tradition, II/2, p. 382-383. 
the Tome of Leo and explained that there are two operations in one and the same Christ - that of His divinity and that of His humanity ${ }^{194}$. This model of reasoning is more close to that of the Council of Chalcedon than that of Cyril of Alexandria.

Nevertheless, many pro-Chalcedonian writers were disposed to the doctrine of a single composite operation as consisted with Chalcedonian formu$\mathrm{la}^{195}$. They were convinced that two operations would necessarily conflict to each other. Such a conviction is evident from the Miathelite Florilegium. Beside the passages from the writings of ancient Fathers and Councils quoted by both, the Miaenergists and the Dyenergists, there was also cited a number of Chalcedonian writers like pope Vigilius (500-555, pope 537-555), the Patriarch Menas († 552, patriarch 536-552), Symeon the Stylite (521-597), Anastasios of Antioch († 598, patriarch 559-70 and 593-598) and others ${ }^{196}$.

Anastasius, pro-Chalcedonian patriarch of Antioch was preparing the way for the seventh-century Miaenenergist debate ${ }^{197}$. He preached a single operation in Christ. In the mystery of Christ there absolutely was not place for any opposition or deliberation, since a single will and a single volition existed in him $^{198}$.

Probably the most influential pro-Chalcedonian theologian of the sixth and seventh century who advanced the Miathelite views was Theodore, bishop of Pharan (c. 570-638) ${ }^{199}$. He was considered at the Lateran Council of 649 as the first author of the novelty, that is of the Miatheletism ${ }^{200}$. Cyrus of Alexandria († 642, patriarch c. 633-642) in his letter to Sergius of Constantinople (565638, patriarch 610-638) added the writings of Theodore of Pharan ${ }^{201}$. Theodore was thus reckoned as a significant theologian. According to him, the single hypostasis in Christ implies the single composite operation of Christ's divinity and humanity ${ }^{202}$. The principle of operation is the $\operatorname{Logos}^{203}$. The operation then is divine ${ }^{204}$. Whatever human and divine performed by Christ is the work of $\mathrm{God}^{205}$. Consequently, there is also only one divine will ${ }^{206}$.

\footnotetext{
${ }^{194}$ Cf. Rorem - Lamoreaux, John of Scythopolis, p. 473.

${ }^{195}$ Cf. Lange, Miaenergetism, p. 330.

${ }^{196}$ Cf. Brock, A Monothelete Florilegium in Syriac, p. 35-44.

${ }^{197} \mathrm{Cf}$. Frend, The Rise of the Monophysite Movement, p. 318.

${ }^{198}$ Cf. Brock, A Monothelete Florilegium in Syriac, p. 40-42.

${ }^{199}$ Cf. Lange, Miaenergetism, p. 331.

${ }^{200} \mathrm{Cf}$. ACO II/1, 118, 9-11.

${ }^{201} \mathrm{Cf} . \mathrm{ACO} \mathrm{II} / 2,2,586,5-8$.

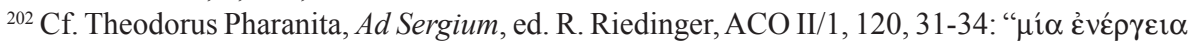

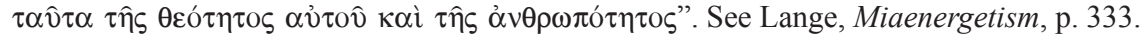

${ }^{203}$ Cf. Theodorus Pharanita, Ad Sergium, ACO II/1, 124, 3-7.

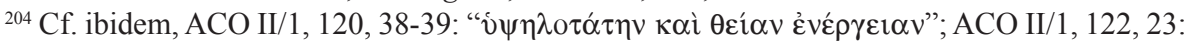

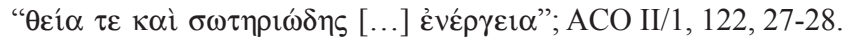

${ }^{205}$ Cf. ibidem, ACO II/1, 120, 31-34.

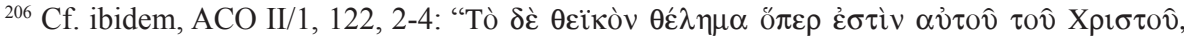

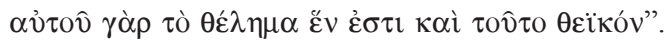


Though the initiation of Christ's activity comes from the Logos, the operation itself is performed by the means of the body and the soul filled with mind $^{207}$. Theodore maintains the single and common operation of the Logos, of the human mind and of the sensual and organic body in Christ ${ }^{208}$. Christ worked everything in the single and indivisible mode ${ }^{209}$. The governing principle of Christ's activity thus is the Logos as the operator and creator ( $\tau \varepsilon \chi v^{\prime} \tau \eta \eta v$

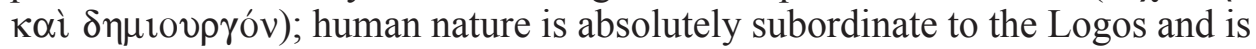

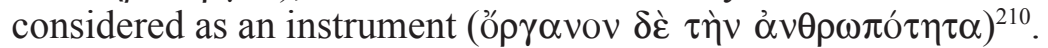

According to Theodore, the single operation of the Logos embraces not only miracles ${ }^{211}$ but also human natural experiences like toil, hunger, thirst ${ }^{212}$, suffering, sadness and trouble ${ }^{213}$. The Logos yielded to them when he willed ${ }^{214}$, since the human soul is too weak even to govern the properties of the flesh ${ }^{215}$. The power of the Logos dominated Christ's humanity to such extent that Theodore even repudiates some natural earthly properties of the body of Christ ${ }^{216}$.

Theodore's reasoning in the sphere of Christ's volition was not coherent. He could not explain subjectivity of Christ's human experiences and sufferings which are not consistent with the Logos. Theodore's views are in accordance with the Christology of the Logos-sarx type. He tends to be a follower especially of Cyril of Alexandria and Pseudo-Areopagite. Theodore had followers among the pro-Chalcedonian bishops of the seventh centuries, which vividly discussed the question of Christ's operation ${ }^{217}$. In the sixth and seventh centuries thus Miaenergism flourished in the sphere of the Chalcedonian theology as a speculation well-rooted in the theological reflection of the previous centuries, especially in the Logos-sarx model of Christology.

\section{(Summary)}

The article discusses the question of the relation between the sixth-century Miaenergism, which is the idea of Christ having one divine-human operation, and the Logos-sarx type of Christology. The purpose of the article is to argue that the Miaenergism was dependent on the Christology centered on the divinity of incar-

\footnotetext{
${ }^{207}$ Cf. ibidem, ACO II/1, 120, 24-26; ACO II/1, 122, 8-18; ACO II/1, 122, 10-18.

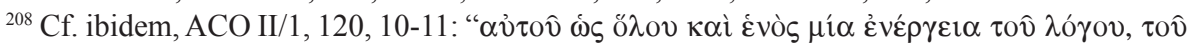

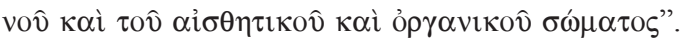

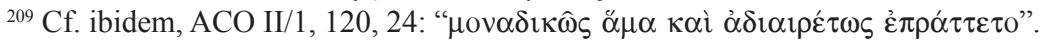

${ }^{210} \mathrm{Cf}$. ibidem, ACO II/1, 124, 3-7.

${ }^{211} \mathrm{Cf}$. ibidem, ACO II/1, 122, 8-18.

${ }^{212} \mathrm{Cf}$. ibide, ACO II/1, 120, 15-18 and 122, 8-18.

${ }^{213} \mathrm{Cf}$. ibidem, ACO II/1, 122, 10-18.

${ }^{214}$ Cf. ibidem, ACO II/ $1,120,15-18$.

${ }^{215} \mathrm{Cf}$. ibidem, ACO II/1, 122, 32-39.

${ }^{216} \mathrm{Cf}$. ibidem, ACO II/1, 130, 21-22.

${ }^{217}$ Cf. M. Jankowiak, The Invention of Dyotheletism, StPatr 63 (2013) 335.
} 
nate Christ. The Logos was acknowledged as the active principle even of Christ's humanity, so that the human volition and operation of Christ was neglected in favor of the Logos. This model of Christology was being developed especially from the second century in the writings of Clemens of Alexandria, Origen, Athanasius of Alexandria and Apollinarius of Laodicea; then it was continued by Cyril of Alexandria and Severus of Antioch; it also influenced Leontius of Byzantium and Theodore of Pharan. The Miaenergism of the sixth and then of the seventh century was being developed on a ground of the Logos-sarx type of Christology, although it acknowledged the Dyophysitism of Chalcedon.

\section{CHRYSTOLOGIA LOGOS-SARX A MONOENERGIZM VI WIEKU}

\section{(Streszczenie)}

Artykuł omawia kwestię zależności między monoenergizmem jako poglądem głoszącym, że w Chrystusie działa tylko natura boska, a chrystologią typu Logossarx. Celem artykułu jest udowodnienie, że monoenergizm był zależny od chrystologii skoncentrowanej na Bóstwie wcielonego Chrystusa. Logos został uznany za zasadę działająca, nawet jeśli chodzi o ludzką naturę Chrystusa, tak że ludzka wola i działanie Chrystusa były umniejszane wobec Logosu. Ten model chrystologii był rozwijany szczególnie od II wieku w pismach Klemensa Aleksandryjskiego, Orygenesa, Atanazego Aleksandryjskiego i Apolinarego z Laodycei; następnie był kontynuowany przez Cyryla Aleksandryjskiego i Sewera z Antiochii; chrystologia tego typu miała wpływ na Leoncjusza z Bizancjum i Teodora z Faran. Monoenergizm w VI, a następnie w VII w. rozwijał się więc na gruncie chrystologii typu Logos-sarx, chociaż uznawał chalcedoński diofyzytyzm.

Key words: Christ, Logos, Logos-sarx, Miaenergetism, divinity, humanity, nature, mind, volition, will, operation.

Słowa kluczowe: Chrystus, Słowo, Logos-sarx, monoenergizm, bóstwo, człowieczeństwo, natura, umysł, wola, działanie.

\section{BIBLIOGRAPHY}

\section{Sources}

Apollinaris von Laodicea und seine Schule. Texte und Untersuchungen, ed. H. Lietzmann, vol. 1, Tübingen 1904.

Aristoteles, De anima, ed. G. Biehl, Lipsiae 1896.

Aristoteles, Ethica nicomachea, ed. F. Susemihl - O. Apelt, Lipsiae 1903.

Athanasius AleXandrinus, De incarnatione contra Apollinarium, PG 26, 1093A - 1165B.

Athanasius Alexandrinus, De incarnatione Verbi, PG 25, 96D - 197A.

Athanasius Alexandrinus, Epistula IV ad Serapionem, PG 26, 637A - 676C.

Athanasius Alexandrinus, Orationes contra Arianos, PG 26, 12-525A.

Athanasius Alexandrinus, Tomus ad Antiochenos, PG 26, 796A - 809C. 
Clemens Alexandrinus, Excerpta e Theodoto, ed. F.-M. Sagnard, SCh 23, Paris 1970.

Clemens Alexandrinus, Paedagogus, ed. C. Mondesert - Ch. Matray - H.I. Marrou, SCh 158, Paris 1970.

Clemens Alexandrinus, Protrepticus, ed. C. Mondesert, SCh 2, Paris 1949.

Clemens Alexandrinus, Stromata, ed. O. Stählin, GCS 15, Leipzig 1906.

Concilium Lateranense a. 649 celebratum, ed. R. Riedinger, ACO II/1, Berolini 1984.

Concilium Universale Constantinopolitanum Tertium (680-681), ed. R. Riedinger, ACO

II/2,1: Actiones I-XVIII, Berolini 1990; ACO II/2, 2: Actiones XII-XVIII. Epistulae.

Indices, Berolini 1992.

Cyrillus Alexandrinus, Ad reginas de recta fide oratio altera, PG 76, 1336C - 1420D.

Cyrillus Alexandrinus, Apologeticus contra Theodoretum, PG 76, 391B - 452C.

Cyrillus Alexandrinus, Commentarii in Joannem, PG 73 (libri I-VI); PG 74, 9A - 104C

(fragmenta librorum VII et VIII); PG 74, 105A - 756C (libri IX-XII).

Cyrillus Alexandrinus, De incarnatione Unigeniti, PG 75, 1189B - 1253B.

Cyrillus AlexAndrinus, De recta fide ad reginas, PG 76, 1201A - 1336B.

Cyrillus Alexandrinus, De Trinitate dialogi, PG 75, 660A - 1124C.

Cyrillus Alexandrinus, Epistulae, PG 77, 9A - 390D.

Cyrillus Alexandrinus, Fragmenta in Epistulam ad Hebraeos, PG 74, 953A - 1005C.

Cyrillus Alexandrinus, Quod unus sit Christus, PG 75, 1253C - 1361C.

Cyrillus Alexandrinus, Thesaurus, PG 75, 24A - 656D.

Decrees of the Ecumenical Council, ed. N.P. Tanner, vol. 1: Nicaea I to Lateran V, Washington 1990.

Doctrina Patrum de Incarnatione Verbi, ed. F. Diekamp, Münster 1907.

Eusebius Caesariensis, De ecclesiastica theologia, ed. E. Klostermann, GCS 14, Eusebius

Werke 4, Leipzig 1906, 59-182.

Eusebius Caesariensis, Historia ecclesiastica, ed. G. Bardy, SCh 41, Paris 1955.

Eustathius Antiochensis, Fragmenta, PG 18, 673D - 698B.

Ignatius Antiochenus, Epistulae, ed. Th. Camelot, SCh 10, Paris 1951.

Irenaeus, Adversus haereses, ed. A. Rousseau - L. Doutreleau, III, SCh 211, Paris 1974; IV, SCh 100, Paris 1955; V, SCh 153, Paris 1969.

Iustinus, Apologiae pro Christianis, Dialogus cum Tryphone, ed. M. Marcovich, PTS 38,

Berlin - New York 1994.

Leontius Byzantinus, Contra nestorianos et eutychianos lib. III, PG 86/1, 1268-1396.

Leontius Byzantinus, Solutio argumentorum a Severo obiectorum, PG 86/2, 1916C - 1945D.

Leontius Hierosolymitanus, Contra nestorianos, PG 86/1, 1400-1768.

Liberatus Diaconus, Breviarium causae Nestorianorum et Eutychianorum, PL 62, 969A - 1052B.

Nestorius, Fragmenta, ed. F. Loofs, in: Nestoriana: Die Fragmente Des Nestorius, Halle 1905.

Origenes, Contra Celsum, ed. M. Borret, I-II, SCh 132, Paris 1967, V-VI, SCh 147, Paris 1969.

Origenes, De principiis, ed. H. Crouzel - M. Simonetti, I-II, SCh 252, Paris 1978, III-IV, SCh 268, Paris 1980.

Pseudo-Didymus, De Trinitate, PG 39, 270A - 992C.

Pseudo-Dionysius Areopagita, Epistula IV ad Gaium, PG 3, 1072A-C.

Pseudo-Dionysius Areopagita, De divinis nominibus, PG 3, 585A - $996 \mathrm{~B}$.

Severus Antiochenus, Fragmenta (in English), in: Allen P. - Hayward C.T.R., Severus of Antioch, London - New York 2004, 59-173. 
Tertullianus, Adversus Marcionem, ed. A. Kroymann, CSEL 47, Lipsiae 1906, 290-650. Tertullianus, Adversus Praxean, ed. A. Kroymann, CSEL 47, Lipsiae 1906, 227-289. Tertullianus, De carne Christi, ed. J.-P. Mahé, SCh 216, Paris 1975.

Theodorus Mopsuestenus, Fragmentum in Matthaeum, PG 66, 1004D.

\section{Literature}

Allen P. - Hayward C.T.R., Severus of Antioch, London - New York 2004.

Brock S., A Monothelete Florilegium in Syriac, in: S. Brock, Studies in Syriac Christianity: History, Literature and Theology, Hampshire 1992, 35-45.

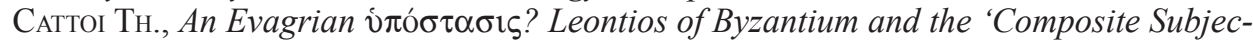
tivity' of the person of Christ, StPatr 68 (2011) 133-147.

Crouzel H., Orygenes, transl. into Polish J. Margański, Kraków 2004.

Daniélou J. - Marrou H.I., The Christian Centuries, vol. 1: The First Six Hundred Years, transl. into English V. Cronin, London 1964.

Dihle A., The Theory of Will in Classical Antiquity, Berkeley - Los Angeles - London 1982.

Frede M., A Free Will. Origins of the Notion in Ancient Thought, Berkeley - Los Angeles - London 2011.

Frend W.H.C., The Rise of the Monophysite Movement. Chapters in the History of the Church in the Fifth and Sixth Centuries, Cambridge 2008.

GiLbert N.W., The Concept of Will in Early Latin Philosophy, „Journal of the History of Philosophy" 1 (1963) fasc. 1, 17-35.

Gray P.T.R., Introduction, in: Leontius of Jerusalem. Against the Monophysites: Testimonies of the Saints and Aporiae, ed. and transl. P.T.R. Gray, Oxford 2006, 1-43.

Gray P., Neo-Chalcedonianism and The Tradition: From Patristic to Byzantine Theology, ByF 8 (1982) 61-70.

GreIG J., The Dilemma of Deliberation: On the faculty and Mode of Willing in Aristotle and Maximus the Confessor, https://www.scribd.com/document/127364720/On-the-Faculty-and-Mode-of-Willing-in-Aristotle-and-Maximus-the-Confessor, 2-6 [08.04.2017].

Grillmeier A., Christ in Christian Tradition, vol. 1: From the Apostolic Age to Chalcedon (451), transl. into English J. Bowden, Atlanta 1975.

Grillmeier A. - Hainthaler T., Christ in Christian Tradition, vol. 2: From the Council of Chalcedon (451) to Gregory the Great (590-604), part 2: The Church of Constantinople in the Sixth Century, transl. into English P. Allen - J. Cawte, London 1995.

Harnack A., History of Dogma, transl. into English N. Buchanan, vol. 4, Boston 1898.

Höln H.-J., The Preacher, in: A. Grillmeier - T. Hainthaler, Christ in Christian Tradition, vol. 2: From the Council of Chalcedon (451) to Gregory the Great (590-604), part 2: The Church of Constantinople in the Sixth Century, transl. into English P. Allen - J. Cawte, London 1995, 129-147.

Hovorun C., Will, Action and Freedom: Christological Controversies in the Seventh Century, Leiden - Boston 2008.

JankowiaK M., The Invention of Dyotheletism, StPatr 63 (2013) 335-342.

Kelly J.N.D., Early Christian Doctrines, London 1968.

Lange Ch., Miaenergetism - A New Term for the History of Dogma?, StPatr 63 (2013) 327-333.

Naumowicz J., Leoncjusz z Bizancjum, EK X 794-795.

ReEs S., Leontius of Byzantium and His Defence of the Council of Chalcedon, HTR 24 (1931) fasc. 2, 111-119. 
Rorem P. - Lamoreaux J.C., John of Scythopolis on Apollinarian Christology and the Pseudo-Areopagite's True Identity, ChH 62 (1993) fasc. 4, 469-482.

SesboüÉ B., Treść tradycji: reguła wiary i symbole (II-V wiek), in: Historia dogmatów, vol. 1: Bóg zbawienia, ed. B. Sesboüé - J. Wolinski, transl. into Polish P. Rak, Kraków 1999, 63-120.

Szczur P., Leoncjusz z Jerozolimy, EK X 795-796.

Szram M., Ciało zmartwychwstałe w myśli patrystycznej przełomu II i III wieku, Lublin 2010.

SzRam M., Neochalcedonizm, EK XIII 902-903.

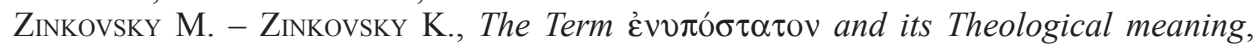
StPatr 63 (2013) 313-325. 
